\title{
Cenozoic Stratigraphic and Structural Framework of Southwestern Utah
}

GEOLOGICAL SURVEY PROFESSIONAL PAPER 1149
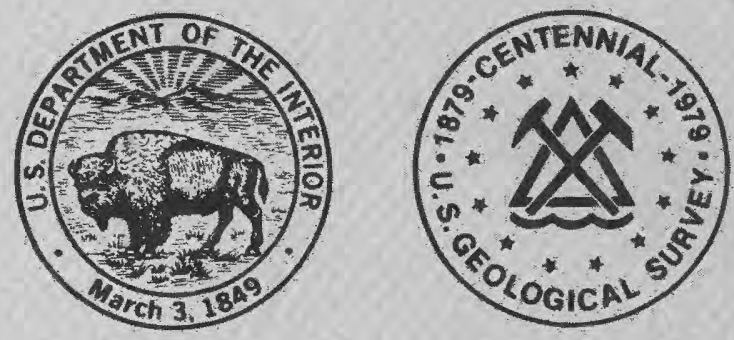


\section{Cenozoic Stratigraphic and Structural Framework of Southwestern Utah}

By PETER D. ROWLEY, THOMAS A. STEVEN,

JOHN J. ANDERSON, and CHARLES G. CUNNINGHAM

GEOLOGICAL SURVEY PROFESSIONAL PAPER 1149

A summary of the Cenozoic sedimentary and volcanic stratigraphy of southwestern Utah, and the structures that controlled deposition of the strata and that displaced these strata

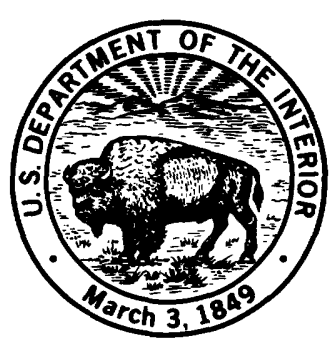




\section{UNITED STATES DEPARTMENT OF THE INTERIOR}

CECIL D. ANDRUS, Secretary

\section{GEOLOGICAL SURVEY}

H. William Menard, Director

Library of Congress Cataloging in Publication Data

Main entry under title:

Cenozoic Stratigraphic and Structural Framework of Southwestern Utah

(Geological Survey Professional Paper 1149)

Bibliography: p. 17

1. Geology, Stratigraphic-Cenozoic. 2. Geology-Utah. I. Rowley, Peter D. II. Series:

United States Geological Survey Professional Paper 1149

QE690.C438 $551.7^{\prime} 8^{\prime} 09792$

79-17228

For sale by the Superintendent of Documents, U.S. Government Printing Office Washington, D.C. 20402

Stock Number 024-001-03227-9 


\section{CONTENTS}

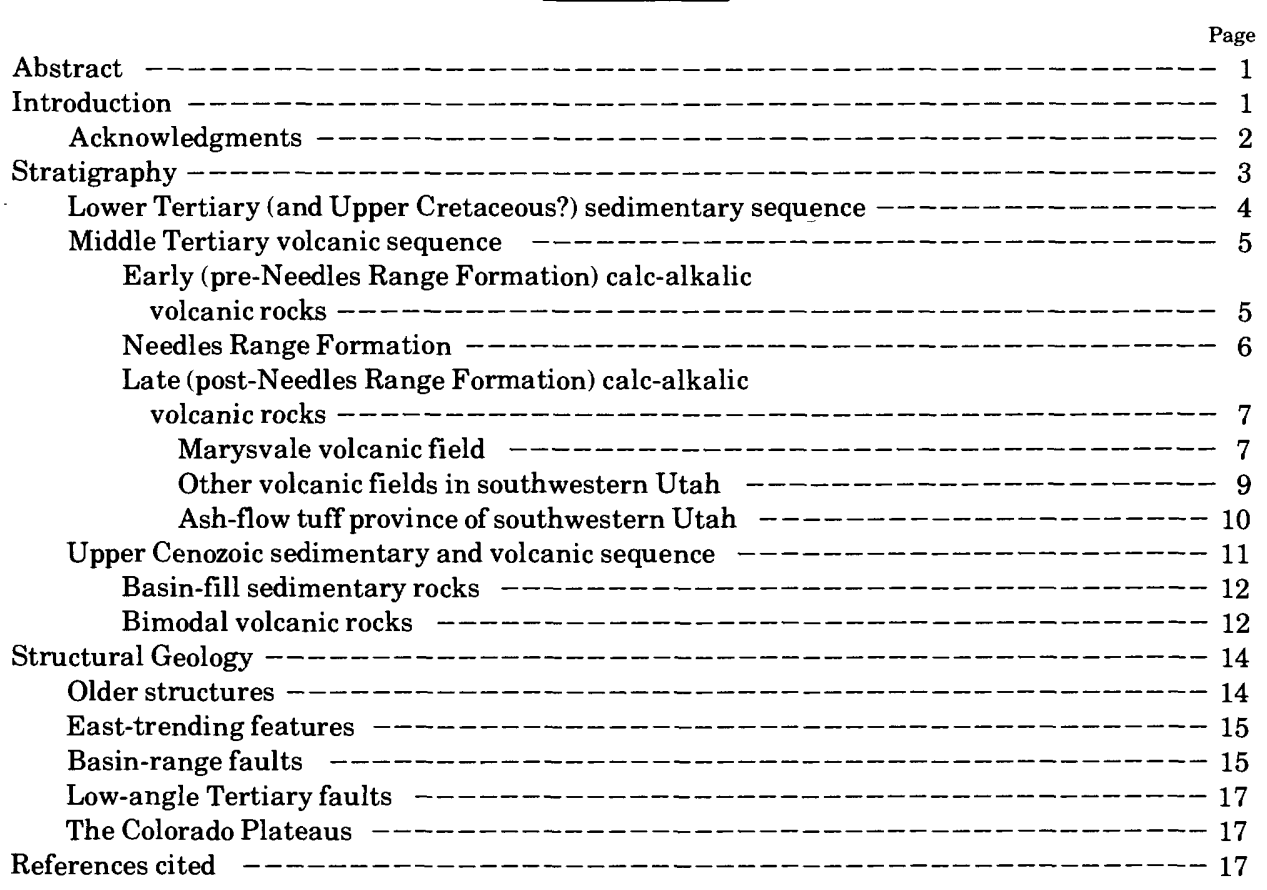

\section{ILLUSTRATIONS}

FIGURES 1. Map of physiographic and major structural features of southwestern Utah--------

2. Generalized lithology map of southwestern Utah_-

3. Correlation chart for Cenozoic rocks of southwestern Utah

4. North-south cross section across Marysvale volcanic field - - - - - -

\section{METRIC-INCH-POUNDSYSTEM EQUIVALENTS}

\begin{tabular}{|c|c|c|}
\hline Metric unit & Multiplied by & $\begin{array}{l}\text { To give inch-pound } \\
\text { system equivalent }\end{array}$ \\
\hline
\end{tabular}





\title{
CENOZOIC STRATIGRAPHIC AND STRUCTURAL FRAMEWORK OF SOUTHWESTERN UTAH
}

\author{
By Peter D. Rowley, Thomas A. Steven, John J. Anderson,' \\ and Charles G. CUNNINGHAM
}

\begin{abstract}
Cenozoic rocks of southwestern Utah chronicle a complex history of early Tertiary sedimentation followed by middle and late Tertiary and Quaternary volcanism and basin-fill sedimentation. Sedimentation in latest Cretaceous(?) to Oligocene time took place largely in two broad basins that developed east of a highland formed during the Sevier orogeny in Late Cretaceous time. Calc-alkalic volcanism began in early Oligocene time and continued into the early Miocene; many widely scattered, partly clustered, intermediate-composition stratovolcano complexes formed in two east-northeast-trending belts. The intervening lowlands were covered by thin but widespread ashflow tuff sheets. Little deformation took place during most of early sedimentation and calc-alkalic volcanism, but minor faulting can be documented locally, especially along several east-trending lineaments. The Basin and Range and Colorado Plateaus provinces appear to have begun to separate into identifiable structural entities about 26 m.y. ago.
\end{abstract}

About 20 m.y. ago, east-west extension started to imprint a northerly striking pattern of basin-range faults onto the older easttrending igneous belts and underlying sedimentary rocks the present structural and topographic grain of southwestern Utah formed. Uplifted blocks were eroded and sediments were deposited in the adjacent developing basins. Concurrently a bimodal assemblage of mostly small volumes of basaltic and rhyolitic rocks was erupted. Basalt flows are very widely distributed, but the rhyolitic rocks were erupted from local centers, many of which are located along the east-trending lineaments within the older igneous belts.

Mineralization took place at many volcanic centers during the waning stages of the calc-alkalic volcanism, and around some of the younger rhyolitic centers episodically throughout the span of bimodal volcanism.

\section{INTRODUCTION}

Most of southwestern Utah is covered by continental sedimentary and volcanic rocks of Cenozoic age. The volcanic rocks are especially important because of their associated metallic mineral resources, and exploration interest is high. Southwestern Utah also has potential for important petroleum and geothermal resources. This paper reviews the lithology of the Cenozoic rocks,

\footnotetext{
${ }^{1}$ Department of Geology, Kent State University, Kent, Ohio 44242.
}

their mode of occurrence, and the structures that affect them, as an aid to the various exploration programs.

The area described extends from the eastern part of the Basin and Range province across the adjacent High Plateaus subprovince of the Colorado Plateaus province (fig. 1). This area encompasses the igneous province of southwestern Utah; this province extends westward into southeastern Nevada but is separated from the igneous province of west-central Utah by mountain ranges underlain almost entirely by pre-Cenozoic rocks.

The work leading to this report was begun in the 1960's by Anderson and Rowley as a regional study of the volcanic terrane in the southwestern High Plateaus and adjacent part of the Basin and Range province. Results of this study were published by J. J. Anderson (1971), Anderson and others (1975), Rowley, Anderson, and Williams (1975), and Rowley (1978). Rowley later completed some unfinished work of the late J. Hoover Mackin in the Iron Springs mining district and published a series of geologic maps (Mackin and Rowley, 1975, 1976; Mackin and others, 1976; Rowley, 1975, 1976; Rowley and Threet, 1976). In 1975, Steven, Cunningham, and others began a detailed investigation of the Marysvale mining district. Preliminary reports on several aspects of this work have been published by Steven and others $(1977,1979)$; Steven, Cunningham, and Rowley (1978); Steven, Rowley, and Cunningham (1978); Steven and Cunningham (1979a); Cunningham and Steven (1977, 1978a, 1979a, 1979b); and Cunningham, Steven, and Naeser (1978). A brief study of young rhyolites in southwestern Utah and their geothermal potential resulted in reports by Lipman and others (1978); Mehnert, Rowley, and Lipman (1978); and Rowley, Lipman, and others (1978). More recently, these separate studies have been consolidated into a comprehensive investigation of the geology and mineral resource potential of the Richfield $2^{\circ}$ quadrangle, in which all four of the present authors are participating. A series of geologic maps also is being published (Steven, 1978, 1979a, 1979b; Cunningham and Steven, 




FIGURE 1. - Physiographic features and major structural features of southwestern Utah. Basin and Range - Colorado Plateaus boundary shown by heavy short-dashed line; Pavant Range, Tushar Mountains, and named plateaus belong to the High Plateaus subprovince. Central part of Pioche-Marysvale igneous belt on north, and of Delamar-Iron Springs igneous belt on south, patterned. Dot-dash line, east edge of major Sevier thrust faults, modified from Crosby (1973). Heavy long-dashed lines, axes of lineaments, consisting from north to south of the Black Rock, Blue Ribbon, and Timpahute lineaments. Fine dashed line on the north, approximate minimum boundaries of depositional basins of the North Horn to Crazy Hollow Formations; to the south, the Claron Formation and related rocks. Tushar highland is between them. A, Antimony; B, Boulder; Be, Beaver; C, Circleville; CC, Cedar City; CF, Cove Fort; E, Enterprise; Es, Escalante; F, Fillmore; H, Hurricane; K, Kanab; L, Loa; M, Minersville; Ma, Marysvale; Mi, Milford; P, Panguitch; Pa, Parowan; R, Richfield; S, Stateline mining district; Sa, Salina; SG, St. George.

1978b; 1979c, 1979d; Rowley, 1979; Rowley and others, 1979). A preliminary "state of the art" compilation of the geology of the Richfield quadrangle (Steven, Rowley, and others, 1978) was prepared early in this investigation and is being significantly modified by continuing field studies. The present report summarizes data from all these studies.

\section{ACKNOWLEDGMENTS}

Collaboration and conversations with P.L.Williams, H. H. Mehnert, R. E. Anderson, E. H. McKee, C. W. Naeser, R. J. Fleck, G. P. Eaton, M. G. Best, M. G. Nelson, G. A. Wadsworth, K. E. Budding, J. M. Edwards, W. K. Hamblin, D. S. Barker, G. A. Izett, M. M. 


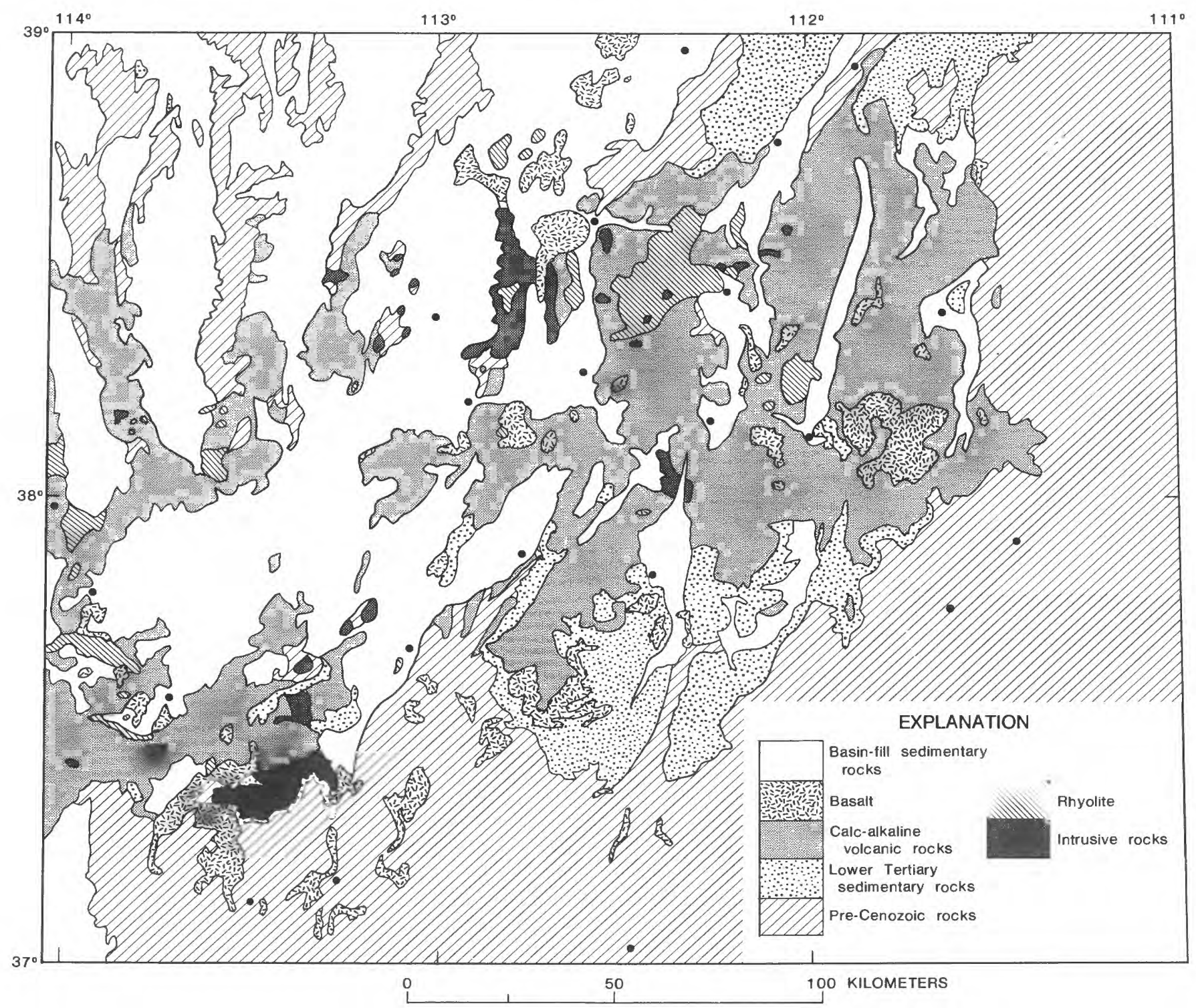

FiguRE 2.-Generalized lithology map of southwestern Utah, modified from Hintze (1963). Dots mark locations referred to in figure 1.

Machette, D. A. Lindsey, D. R. Shawe, J. T. Abbott, G. L. Galyardt, T. D. Fouch, Eugene Callaghan, A. G. Everett, H. H. Sturr, and the late J. H. Mackin helped formulate many concepts given in this paper. Thesis work by J. M. Sigmund and S. H. Decatur of Kent State University also contributed significant data. Suggestions by R. E. Anderson and K. A. Sargent materially improved the manuscript.

\section{STRATIGRAPHY}

The Cenozoic rocks of southwestern Utah (fig. 2) comprise three broad sequences that differ in age and rock type and that formed in different tectonic environments. The oldest of these is made up of uppermost Cretaceous(?) to Oligocene fluvial and lacustrine rocks that unconformably overlie Mesozoic and Paleozoic rocks. These rocks were deposited in marginal basins east of highlands formed during eastward-directed thrust-faulting and folding of the Sevier orogeny and warping of the Laramide orogeny. A middle Tertiary volcanic sequence consisting mostly of upper Oligocene and lower Miocene calc-alkalic volcanic rocks overlies the lower Cenozoic sedimentary sequence. The volcanic rocks, underlain by related plutons, formed many scattered, partly clustered, intermediate-composition stratovolcanoes separated by broad areas covered by 
thin, regionally distributed silicic ash-flow tuffs. The youngest sequence consists of upper Cenozoic fluvial and lacustrine deposits that filled developing basins during basin-range tectonism, and of a bimodal volcanic assemblage of alkali basalt and high-silica alkali rhyolite that was erupted episodically during the same time span. Basin-range tectonism and related volcanism both began 21-20 m.y. ago in southwestern Utah and have continued to the present.

\section{LOWER TERTIARY (AND UPPER CRETACEOUS?) SEDIMENTARY SEQUENCE}

Lower Tertiary sedimentary rocks in southwestern Utah were deposited in at least two separate basins and as thin patches farther west. The most widespread basin contains a poorly studied succession, named the Claron
Formation, which consists of more than $300 \mathrm{~m}$ of fluvial and lacustrine strata. These rocks were loosely referred to as Wasatch Formation in early reports; the name Claron was applied by Leith and Harder (1908) to rocks of this assemblage in the Iron Springs district; and Mackin (1968) described the Iron Springs rocks in more detail. The formation is well exposed in the Red Hills (Threet, 1963b), and nearly continuous outcrops occur over large areas in the High Plateaus (Anderson and Rowley, 1975). The formation also is found in widely separated exposures in other parts of the Basin and Range province, such as the Bull Valley Mountains (Blank, 1959), Pine Valley Mountains (Cook, 1957), and Black Mountains (fig. 3). Relations in all these areas suggest deposition in a broad, flat basin that extended across the present southern High Plateaus and adjacent parts of the Basin and Range province as far west as the eastern or central Bull Valley Mountains.

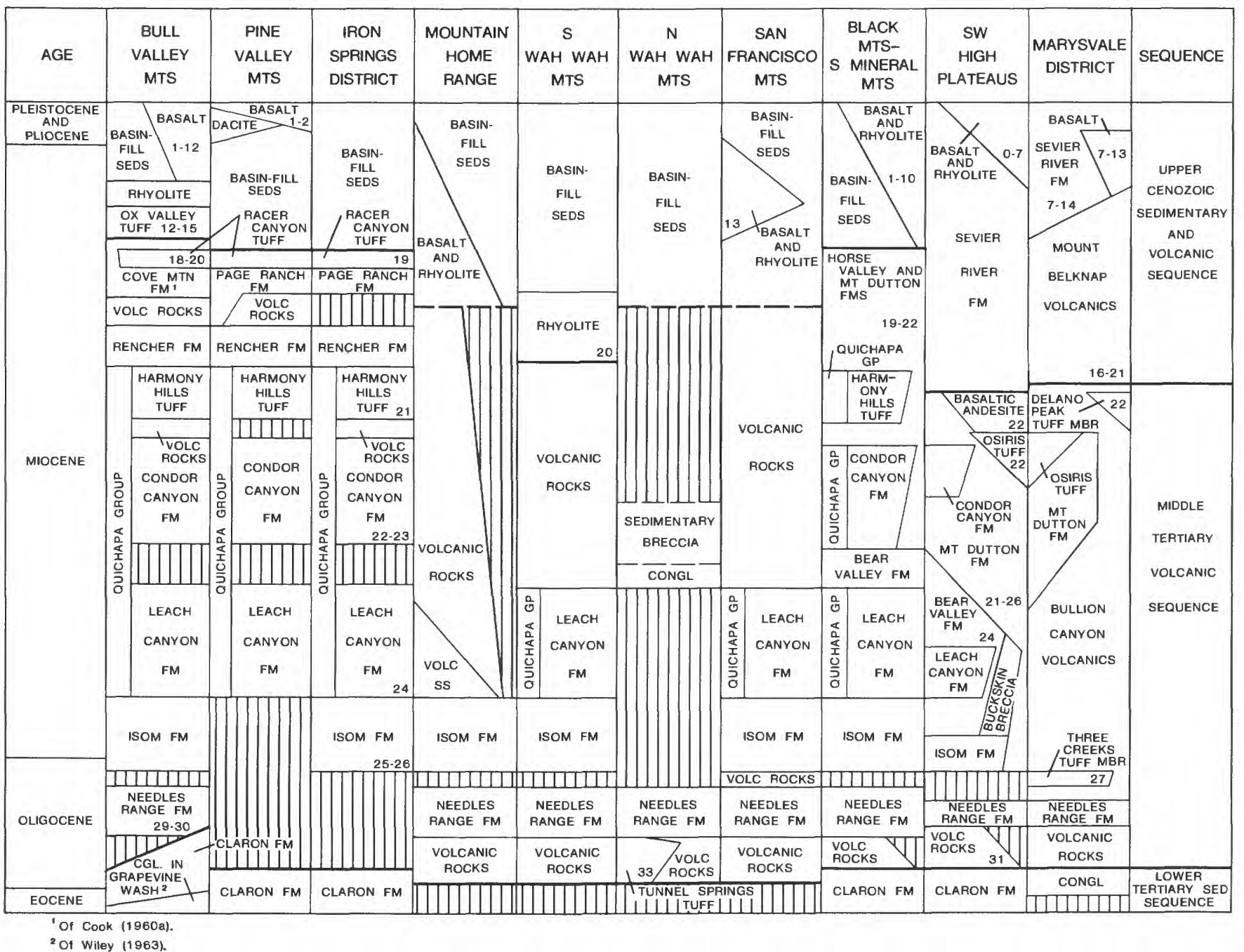

FIGURE 3.-Generalized correlation chart for Cenozoic rocks, excluding Holocene deposits, of southwestern Utah. Vertical lines, strata absent. Local unconformities not shown. Numbers refer to K-Ar ages, rounded to the nearest million years. Heavy lines, boundaries of stratigraphic sequences. Lines dashed where approximately located. 
In the eastern Bull Valley Mountains, the thick fanglomerate in Grapevine Wash (Wiley, 1963), was deposited in front of, and was locally overridden by, an eastward-advancing thrust sheet during the Sevier orogeny (Cook, 1957, 1960a; Wiley, 1963; Rowley, Anderson, and others, 1978b). This unit, presumably of latest Cretaceous and earliest Tertiary age, underlies and is gradational into basal rocks of the Claron Formation (Wiley, 1963).

The Claron Formation was deposited through a broad span of time, from at least early Eocene through middle Oligocene. Locally, deposition may have begun as early as Paleocene or latest Cretaceous. Most of the age data comes from the upper part of the formation, which locally is interbedded with (Blank, 1959; Mackin, 1960; Wiley, 1963), or more commonly overlain by, ash-flow tuffs of the 30- to 29-m.y.-old Needles Range Formation, discussed later. R. E. Anderson (oral commun., 1976) found volcanic clasts in basal conglomerate of the Claron east of the Pine Valley Mountains, indicating that here the formation may be all of middle to late Oligocene age. The lower part of the Claron Formation is much more poorly known. On the basis of a detailed stratigraphic and paleontologic study of the basal Tertiary sedimentary rocks of the southeastern High Plateaus, Bowers (1972) named two new formations (Upper Cretaceous and Paleocene(?) Canaan Peak and Paleocene(?) Pine Hollow Formations) for rocks that are generally correlative with the lower part of the Claron and retained informal names for units that are correlated with the upper part of the Claron. Much more detailed work is needed to establish how widely these units of Bowers extend and how they fit with the Claron assemblage.

A different succession of lower Tertiary sedimentary rocks is exposed in the High Plateaus and adjacent Colorado Plateaus north of the Marysvale volcanic field. Most of these rocks are outside the area of interest to this report and will be mentioned only briefly. This northern succession consists of fluvial and lacustrine sedimentary rocks of the Upper Cretaceous and Paleocene North Horn Formation, the Paleocene and lower Eocene Flagstaff Limestone, the Eocene Colton and Green River Formations, and the Eocene(?) Crazy Hollow Formation. These formations, many bounded by unconformities, have been studied in detail by Spieker $(1946,1949)$ and his students and colleagues, principally from Ohio State University (for example, Stanley and Collinson, 1979). The lithologies of this northern succession differ somewhat from those of the Claron Formation, and separate systems of nomenclature seem justified.

The northern and southern successions of lower Tertiary sedimentary strata are separated by the younger Marysvale volcanic field, which seems to have accumu- lated above an older highland that divided the area east of the Sevier orogenic belt into two basins. This highland, which we call the Tushar highland, trended east across the area now occupied by the Mineral Mountains, Tushar Mountains, and central Sevier Plateau (Callaghan, 1973; Anderson and Rowley, 1975). The only lower Tertiary sedimentary rocks that occur on the highland are patches of conglomerate generally less than $30 \mathrm{~m}$ thick (Earll, 1957; Liese, 1957; Kennedy, 1960, 1963; Callaghan and Parker, 1962a; Cunningham and others, 1978). The margins of the apparent basins are covered by volcanic rocks, but drill log data (Ritzma, 1972) show the Claron to be only $180 \mathrm{~m}$ thick west of Antimony. The Claron in Antimony Canyon, to the southeast, is about $450 \mathrm{~m}$ thick (Williams and Hackman, 1971); here Smith (1957) found conglomerate thickening northward. Stanley and Collinson (1979) noted that in the northern basin south of Salina, carbonate rocks give way southward to clastic sedimentary rocks, some of which are derived from the south.

The third succession of lower Tertiary sedimentary rocks in southwestern Utah consists of local patches of mostly thin, unnamed conglomerate that have been mapped in the San Francisco Mountains (East, 1966), southern House and Confusion Ranges (Hintze, 1974a, b), and Burbank Hills and Cricket Mountains (Hintze, 1963). The rocks pinch out laterally against preexisting hills and are missing in many areas. The hills are especially abundant near the Nevada border and appear to be parts of a highland formed by the Sevier orogeny. The patches of sedimentary rocks probably represent deposition in many local low-lying areas. In adjacent parts of eastern Nevada, however, larger basins formed in which thick sediments of the Sheep Pass and other formations were deposited (Fouch, 1979).

\section{MIDDLE TERTIARY VOLCANIC SEQUENCE}

The middle Tertiary volcanic sequence consists almost entirely of calc-alkalic igneous rocks that range in age from about $35 \mathrm{~m} . \mathrm{y}$. to about $19 \mathrm{~m}$.y. They can be divided into three successive assemblages in which the middle assemblage consists of the Needles Range Formation, a distinctive ash-flow tuff marker unit that occurs throughout most of southwestern Utah. Volcanic rocks below the Needles Range Formation formed local silicic ash-flow sheets and scattered intermediatecomposition stratovolcanoes. These volcanic rocks are lithologically similar to those above the Needles Range Formation.

\section{EARLY (PRE-NEEDLES RANGE FORMATION) CALC-ALKALIC VOLCANIC ROCKS}

Calc-alkalic volcanism in southwestern Utah began in early Oligocene time, about $35 \mathrm{~m} . \mathrm{y}$. ago, and 
between then and eruption of the Needles Range Formation 30-29 m.y. ago, many scattered intermediatecomposition stratovolcanoes formed, and a few regional ash-flow sheets accumulated. No change in composition or eruptive behavior took place during or after eruption of the Needles Range tuffs, and the early rocks are merely the precursors of the more voluminous postNeedles Range volcanic rocks in the same area. They are separated solely because the Needles Range Formation provides such an excellent stratigraphic and structural marker horizon over much of southwestern Utah. Inasmuch as the Needles Range Formation rests directly on the Claron Formation over much of the area, the early volcanoes do not appear to have formed a continuous volcanic field.

Early volcanism in the Marysvale volcanic field formed at least three major pre-Needles Range igneous complexes. North and northwest of Marysvale, one major stratovolcano and several minor flank volcanoes underlie the Needles Range Formation. These volcanoes are made up of intermediate-composition (rhyodacitic?) porphyritic lava flows, flow breccia, and mudflow breccia that in the Marysvale Canyon area, north of Marysvale, are more than $400 \mathrm{~m}$ thick (Steven and Cunningham, 1979b). These rocks are assigned to the Bullion Canyon Volcanics, discussed later. A second early stratovolcano, at least $300 \mathrm{~m}$ thick, is exposed on the scarp of the southern Sevier Plateau, east of Circleville. Mudflow breccia from this volcano resembles the rocks of the overlying Mount Dutton Formation, discussed later. The third complex is represented by the 30.4-m.y.-old (Damon, 1968) Spry laccolith south of Circleville. This intrusion was emplaced into and domed the Claron Formation, thus creating a topographic high against which the Needles Range Formation and younger rocks pinched out (Anderson and Rowley, 1975; Grant, 1979). Mercury prospects occur near the pluton contacts (Doelling, 1975).

Farther south in the High Plateaus, a pre-Needles Range mudflow breccia and a local 31.1-m.y. (Fleck and others, 1975) silicic crystal-poor ash-flow tuff, totalling as much as $50 \mathrm{~m}$ in thickness, occur in the northern Markagunt Plateau and southernmost Sevier Plateau. No source for these rocks has been identified.

In the southern Mineral Mountains, dacitic to andesitic volcanic mudflow breecia and lava flows at least 100 $m$ thick define a local pre- Needles Range volcanic complex, which pinches out southward in the northern Black Mountains. Elsewhere in the Black Mountains, Needles Range Formation rests on Claron Formation except in a few scattered places where Rowley (1976, 1978, and unpub. data, 1978) mapped a regional ashflow tuff generally less than $15 \mathrm{~m}$ thick; this tuff tentatively is correlated with the Indian Peak unit 2 of Con$\operatorname{rad}(1969)$.
Farther west, Stringham (1963) noted pre-Needles Range volcanic rocks in the hills south of the San Francisco Mountains, and Lemmon, Silberman, and Kistler (1973, analyses 11-13) mapped 32.5- to 33.6-m.y.old rhyodacite to andesite lava flows in the central Wah Wah Mountains that probably represent part of an old stratovolcano. These rocks reach thicknesses greater than $400 \mathrm{~m}$ (Hintze, 1974c). In the central and northern Wah Wah Mountains, Burbank Hills, southern Confusion Range, and southern House Range, Bushman (1973) and Hintze (1974a, b) mapped the Tunnel Spring Tuff, a widespread pre-Needles Range silicic ash-flow tuff. The Tunnel Spring Tuff, herein adopted, was defined by Bushman (1973), who described a type section in the Crystal Peak area east of the Tunnel Spring Mountains, which in turn are just east of the Burbank Hills. The tuff is as much as $570 \mathrm{~m}$ thick and locally is overlain by conglomerate as much as $100 \mathrm{~m}$ thick. Elsewhere in the southern Wah Wah Mountains, preNeedles Range volcanic rocks are locally more than 700 $\mathrm{m}$ thick in paleovalleys (Campbell, 1979; M. G. Best, written commun., 1979). In the southern Mountain Home Range, volcanic rocks under the Needles Range Formation are as much as $150 \mathrm{~m}$ thick (Campbell, 1979), whereas in the northern part of the range they are $60-90 \mathrm{~m}$ thick (Best, 1976).

\section{NEEDLES RANGE FORMATION}

The Needles Range Formation was first recognized and defined by Mackin (1960). It is an extremely widespread series of ash-flow sheets covering at least 39,000 $\mathrm{km}^{2}$ according to Shuey, Caskey, and Best (1976). The formation consists of lithologically similar crystal-rich ash-flow tuffs that individually may be more than 500 $\mathrm{m}$ thick near their cauldron sources, but in most places the tuffs are less than $100 \mathrm{~m}$ thick. Mackin (1960) recognized two regional members, a lower Wah Wah Springs Tuff Member and an upper Minersville Tuff Member. On the basis of much more work, Best and others (1973) defined four regional members, which from bottom to top are the Cottonwood Wash Tuff Member, the Wah Wah Springs Tuff Member of Mackin, the Lund Tuff Member (generally equivalent to the abandoned Minersville Tuff Member of Mackin), and the Wallaces Peak Tuff Member. The formation was derived 30-29 m.y. ago (Armstrong, 1970; Fleck and others, 1975) from sources believed to be in the southern Mountain Home Range (M. G. Best, oral commun., 1978) and from the Mount Wilson volcanic center in the Wilson Creek Range of eastern Nevada (Ekren and others, 1977).

Remnants of the formation have been found from the Fish Lake and Awapa Plateaus on the east to as far as 
east-central Nevada on the west (Mackin, 1963; Cook, 1965; Anderson and Rowley, 1975; Shuey and others, 1976). Isolated exposures of Needles Range rocks occur in the Confusion Range about $15 \mathrm{~km}$ north of the area of figure 2 and possibly also in the Little Drum Mountains more than $40 \mathrm{~km}$ north of the area of figure 2 (Best and others, 1973; Pierce, 1974; Shuey and others, 1976). The wide distribution of this formation indicates that most of southwestern Utah was a broad plain of low relief that was studded by scattered earlier stratovolcanoes at the time of deposition of Needles Range Formation. Locally, however, the tuffs filled paleovalleys and pinched out against highlands. In the Mountain Home Range and nearby areas, these highlands consist of Paleozoic rocks (Conrad, 1969; Bushman, 1973), perhaps relics from the Sevier orogeny. To the southeast, the formation was not deposited in the Iron Springs area, perhaps due to a preexisting highland; and on a more local scale, it pinched out against the dome created by the Spry intrusion and against local preexisting stratovolcanoes in the Marysvale volcanic field and elsewhere.

\section{LATE (POST-NEEDLES RANGE FORMATION) CALC-ALKALIC VOLCANIC ROCKS}

The post-Needles Range Formation calc-alkalic volcanic rocks in southwestern Utah comprise two general facies that differ markedly in form and distribution. Central-vent volcanoes (stratovolcanoes, shield volcanoes, and volcanic domes) were concentrated in two generally east trending igneous belts, the PiocheMarysvale belt to the north and the Delamar-Iron Springs belt to the south (fig. 1). Where clustered, these volcanoes were surrounded by broad coalescing aprons of volcaniclastic debris. The low areas between the belts, and between scattered volcanoes within the belts, were covered by the second facies, which consists of thin but widespread regional sheets of ash-flow tuff. The two facies accumulated concurrently and are complexly intertongued in places.

The distribution of major central-vent volcanic fields within the Pioche-Marysvale and Delamar-Iron Springs igneous belts is known in a general way, but internal details within many of these fields are known only locally; and even here the coverage is quite uneven. The Marysvale volanic field is the best known local accumulation, but major problems remain to be solved. The discussion on central-vent volcanic fields will first be on the Marysvale field and then on other volcanic fields and will concentrate in those areas where our information is most complete and will give scant attention elsewhere. This treatment is not intended to indicate the relative importance of the different areas.

\section{MARYSVALE VOLCANIC FIELD}

The largest and best known volcanic accumulation in southwestern Utah is the Marysvale volcanic field, which is more than $100 \mathrm{~km}$ in diameter and covers much of the southern High Plateaus and parts of the adjacent Black Mountains and southern Mineral Mountains of the Basin and Range province. The pioneer regional work in the Marysvale area was done by Dutton (1880) and by Callaghan and his associates (Callaghan, 1938, 1939, 1973; Callaghan and Parker, 1961a, 1961b, 1962a, 1962b; Willard and Callaghan, 1962). More recent work has modified many of the conclusions from these and other earlier studies and has provided new information on the eastern (Williams and Hackman, 1971), southern (Anderson and others, 1975), and central and northern parts (Steven and others, 1977, 1979; Steven, Cunningham, and Rowley, 1978; Steven, Rowley, and Cunningham, 1978; Cunningham and Steven, 1977, 1979a) of the field. Wender and Nash (1979) recently conducted a petrologic study of some samples from the Marysvale area.

The Marysvale field is dominated by voluminous rhyodacitic to andesitic stratovolcanoes and surrounding volcaniclastic aprons. These volcanoes can be divided into a vent facies, consisting of lava flows and flow breccia and subordinate mudflow breccia, which merges radially to an alluvial facies, consisting of mudflow breccia and subordinate conglomerate, sandstone, flow breccia, and lava flows. Some individual stratovolcanoes can be distinguished by distinctive lithology, but elsewhere adjacent volcanoes consist of identical rock types. Locally derived ash-flow tuffs interbed with the central-vent volcanic deposits in many places.

The northern part of the Marysvale volcanic field is dominated by a large pre-Needles Range Formation stratovolcano centered in the northern Tushar Mountains. The eastern flank of this volcano is excellently exposed in Marysvale Canyon, north of Marysvale. The sequences of younger volcanic rocks on the northern and southern flanks of this volcano are strikingly different, and precise correlations are difficult. All these rocks, at least $1,000 \mathrm{~m}$ thick, were included in the Bullion Canyon Volcanics or Dry Hollow Formation of Callaghan (1938). Steven and others $(1977,1979)$, however, abandoned the name Dry Hollow; the rocks of the volcano are herein placed in the Bullion Canyon Volcanics.

The post-Needles Range Formation volcanic rocks on the northern flank of the older stratovolcano consist of a series of ash-flow tuff and tufflava units and viscous intermediate-composition lava flows that intertongue with a small, basaltic andesite shield volcano. One of the ash-flow tuff units, the 27-m.y.-old Three Creeks Tuff Member of the Bullion Canyon Volcanics, extends from its cauldron source in the southern Pavant Range 
around the western and southern flanks of the older stratovolcano and provides a stratigraphic tie between the northern and central parts of the Marysvale field. The whole northern flank assemblage is capped by the Osiris Tuff, a regional ash-flow sheet that was erupted about 22 m.y. ago. The Osiris Tuff will be discussed separately.

The northeastern and eastern flanks of the older stratovolcano are covered by a thick sequence of lava flows, volcanic breccia, and ash-flow tuff that forms much of the northern Sevier Plateau. These rocks are too poorly known to be discussed in detail. Farther south in the central Sevier Plateau, the post-Needles Range Formation volcanic rocks comprise two stratovolcano complexes, each at least $300 \mathrm{~m}$ thick; the older of these is andesitic (Little Table area) and the younger is dacitic (Langdon Mountain area) (Rowley, 1979). These rocks intertongue southward with and overlie the Mount Dutton Formation, to be discussed later.

The southern flank of the older stratovolcano in the northern Tushar Mountains is covered by a mixed assemblage of porphyritic intermediate-composition volcanic mudflow breccia and lava flows of the Bullion Canyon Volcanics, which includes a wedge of the Three Creeks Tuff Member within it. The mudflow breccia appears to have been derived in part from the older stratovolcano and in part, along with the interlayered lava flows, from contemporaneous volcanic activity at several centers. These flank accumulations intertongue southward with the distinctive rocks of the Mount Dutton Formation.

The Mount Dutton Formation (Anderson and Rowley, 1975 ) is an assemblage of crystal-poor dacitic to andesitic rocks erupted from many widespread stratovolcanoes in the southern Sevier Plateau, northern Markagunt Plateau, Black Mountains, and southern Mineral Mountains. Vent-facies lava flows and flow breccia in the centers of the volcanoes give way laterally to a great composite apron of volcaniclastic debris formed by coalescing alluvial facies from the many centers. The Mount Dutton Formation intertongues with the postNeedles Range Formation volcanics in the central Tushar Mountains (fig. 4). The Mount Dutton volcanic centers are concentrated along an east-trending belt (Blue Ribbon lineament, discussed later) that extends from the Circleville Canyon area westward between the Tushar Mountains and the Markagunt Plateau and along the northern margin of the Black Mountains. Most of the rest of the formation belongs to the alluvial facies, which forms aprons that are especially broad to the south, east, and west, where few older or concurrent volcanoes existed to interfere with the outflow. The Mount Dutton Formation was deposited after ash flows of the Needles Range Formation extended into the region; the upper part of the formation is as young as 21 m.y. old.
In the western Black Mountains, a local rhyodacitic stratovolcano complex formed concurrently with some of the Mount Dutton eruptions, and its products, named the Horse Valley Formation (Anderson and Rowley, 1975), intertongue with the upper part of the Mount Dutton Formation (Rowley, 1978). Elsewhere, other distinctive rock types are interlayered with the Mount Dutton Formation. These include the 25-m.y.-old Beaver Member (Anderson and Rowley, 1975; S. H. Decatur, unpub. data, 1978), a flow dome in the southwestern Tushar Mountains and eastern Black Mountains; the 25-m.y.-old Kingston Canyon Tuff Member, an ash-flow tuff in the central and southern Sevier Plateau; and the Antimony Tuff Member, an ash-flow tuff near the top of the formation in the central Sevier Plateau.

Southward, the spreading Mount Dutton alluvial apron encountered other locally derived accumulations in the northern Markagunt Plateau and southern Sevier Plateau. Continued eruptions from the Spry laccolith area and concurrent erosion produced the Buckskin Breccia and related conglomerate and mudflow breccia, which are overlain by the 24-m.y.-old Bear Valley Formation (J. J. Anderson, 1971), an eolian sandstone derived from the west and deposited in easttrending grabens in the northern Markagunt Plateau. Depending on locality, the Mount Dutton alluvial facies underlies, is interlayered between, or overlies these local units.

About 22 m.y. ago, during the period of calc-alkalic volcanic eruptions, the widespread distinctive Osiris Tuff was erupted from a probable caldera source in the central Sevier Plateau. This ash-flow sheet forms an excellent marker horizon that has been mapped over most of the Marysvale volcanic field. Some of the older stratovolcanoes stood above the level of Osiris deposition, but all the lower flanks of these volcanoes and much of the outflow alluvial apron were covered by it. The tuff is very extensive to the east (Williams and Hackman, 1971), where it drained down off the slopes of the volcanoes and spread out on the eastern plain. Another, more local ash-flow tuff, the Delano Peak Tuff Member of the Bullion Canyon Volcanics, was erupted from a caldera source in the central Tushar Mountains; this unit also has been dated as 22 m.y. old, but it stratigraphically overlies the Osiris Tuff.

A flow dome complex in the Lousy Jim Creek area in the southwestern Tushar Mountains (J. M. Sigmund, unpub. data, 1978) also was erupted about 22 m.y. ago, but it overlies both the Osiris Tuff and the Delano Peak Tuff Member.

Quartz monzonite plutons were intruded into the northern part of the Marysvale volcanic field, largely in the area of the pre-Needles Range stratovolcano and its flanking younger volcanics. These stocks probably represent high-level cupolas from a major batholith that was emplaced about $23 \mathrm{~m}$.y. ago, late during the period 
Pavant Range $\longrightarrow$ Tushar Mountains Markagunt Plateau

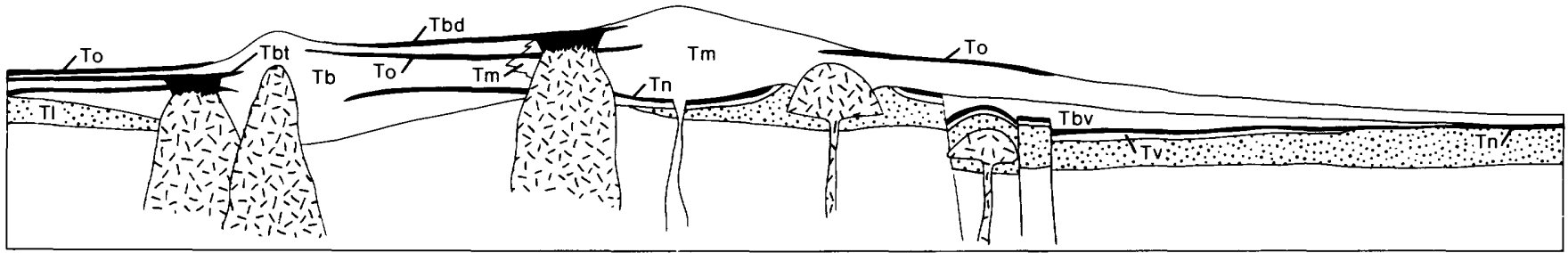

0 5

FiguRE 4.-Schematic north-south cross section across the Marysvale volcanic field, from the Pavant Range to the northern Markagunt Plateau, showing the geology at about $21 \mathrm{~m} . y$. ago. Vertical scale exaggerated; thickness of regional ash-flow tuffs (black) is especially exaggerated. TI, rocks of lower Tertiary sedimentary sequence; Tv, pre-Needles Range volcanic rocks; Tn, Needles Range Formation; Tbv, Bear Valley Formation; Tb, Bullion Canyon Volcanics, including Tbt, Three Creeks Tuff Member and its source cauldron, and Tbd, Delano Peak Tuff Member and its source caldera; Tm, Mount Dutton Formation; To, Osiris Tuff. The named rocks unconformably overlie Mesozoic and Paleozoic sedimentary rocks (not labeled in the figure).

of calc-alkalic volcanism. Although probably representing the source magma for the volcanic rocks, the plutons only locally were emplaced in the centers of older volcanoes. In several places the stocks are unconformably overlain by the Osiris Tuff, indicating local erosion prior to Osiris eruption. Except for the early Spry laccolith, no plutons are exposed in the southern part of the Marysvale volcanic field, where the Mount Dutton Formation is the predominant rock unit. The magma chambers for these little-differentiated volcanic rocks apparently were much deeper and did not aggregate into a rising batholithic body as did those to the north (T. A. Steven, unpub. data, 1978).

The northern part of the Marysvale field contains significant amounts of hydrothermally altered and mineralized rock. Mineralization involved introduction largely of chalcophile elements during the plutonic episode $23 \mathrm{~m}$.y. ago. Base and precious metals have been mined in the area for years. Because discussion of the deposits is outside the scope of this report, the reader is referred to the reports of Callaghan (1973); Steven and others (1977, 1979); Steven, Cunningham, and Rowley (1978); Steven, Rowley, and Cunningham (1978); Steven and Cunningham (1979a), Cunningham and Steven $(1978 \mathrm{a}, 1979 \mathrm{~b})$, and Cunningham, Steven, and Naeser (1978).

\section{OTHER VOLCANIC FIELDS IN SOUTHWESTERN UTAH}

Post-Needles Range Formation calc-alkalic volcanic rocks occur in many other places in southwestern Utah. Most of these accumulations are poorly known. Some may have been large, complex fields, but most appear to have been small, and all seem to have been more deeply eroded than the Marysvale field.
In the Pioche-Marysvale igneous belt just west of the Marysvale field, the central and northern Mineral Mountains contain the largest batholith (nearly 250 $\mathrm{km}^{2}$ ) exposed in Utah. This batholith is mostly mediumto coarse-grained quartz monzonite and granite (Condie, 1960). It has yielded K-Ar ages of 15 to 9 m.y., but $\mathrm{Rb}$-Sr data from 11 analyses of whole-rock samples by C. E. Hedge, U.S. Geological Survey (written commun., 1976), show wide scatter, and a poorly controlled isochron suggests an age for the main batholith of about 35 m.y. The data indicate that sizeable chemical modification, especially Sr loss, occurred at 15 to 7 m.y. ago (Lipman and others, 1978). Recent geologic mapping by Nielson and others (1978) reveals that the batholith is a composite of numerous intrusive phases; the discordant age data thus could have resulted from older plutons being significantly modified by the emplacement of younger ones. The young ages suggest that at least some of the plutons in the Mineral Mountains batholith were intruded during bimodal igneous activity in late Cenozoic time, to be discussed later. Rhyodacitic lava flows and mudflow breccia, possibly related to phases of the batholith, are exposed in scattered places in the southern Mineral Mountains and northern Black Mountains; these rocks occur in areas that are structurally low with respect to the highly uplifted main part of the range. Any other volcanic rocks that may have been related to the batholith have been eroded or are buried in the grabens east and west of the range. Several small mining districts in the southern and eastern Mineral Mountains have produced lead, silver, zinc, tungsten, and gold from or above the contact zone of the batholith and related stocks.

A major volcanic field, having a diameter of more than $40 \mathrm{~km}$, is exposed in the southern San Francisco 
Mountains and adjacent areas to the south. East (1966) estimated that the volcanic rocks in the San Francisco Mountains are about $1,500 \mathrm{~m}$ thick and include tuff as well as andesitic to rhyolitic lava flows. Although Lemmon, Silberman, and Kistler (1973) have documented pre-Needles Range Formation volcanic rocks in this area, most of the rocks appear to overlie the Needles Range Formation (Erickson, 1973). Stringham $(1963,1964)$ noted basaltic to latitic lava flows of undetermined thickness that apparently overlie the Leach Canyon Formation (24 m.y. old) in the area south of the San Francisco Mountains. Dacitic lava flows, ash-flow tuff, and volcanic mudflow breccia still farther south, in the southern Shauntie Hills, were estimated by Rowley (1978) to be at least $500 \mathrm{~m}$ thick and to represent the southern part of a more extensive stratovolcano complex. The San Francisco Mountains and adjacent area have been deeply eroded, and quartz monzonite stocks are widely exposed. K-Ar ages of these stocks and of ash-flow tuffs in this area (Lemmon and others, 1973) range from about 28 m.y. to 21 m.y. The San Francisco mining district and other smaller districts in the volcanic field have produced major amounts of silver, copper, gold, lead, zinc, and subordinate values in other metals (Butler, 1913; Hintze and Whelan, 1973; Shawe and others, 1978). Copper deposits of probable porphyry type, which deserve more detailed exploration, include those at the O.K. and Cactus mines and perhaps those at the Comet and Hickory mines. The San Francisco volcanic field, like the Marysvale field, began forming prior to Needles Range eruptions, and igneous activity continued at least until 21 m.y. ago.

The southern Wah Wah Mountains are underlain by volcanic rocks (Taylor and Powers, 1953; Miller, 1966) that lie adjacent to, and perhaps are an extension of the San Francisco field. The map pattern (Steven, Rowley, and others, 1978) indicates that most of these deposits postdate the Needles Range Formation. The rocks here and just to the north occur in the Pine Grove mining district. This area has been extensively altered to alunite (NG deposit of Parkinson, 1974; Hall, 1978) and mineralized with fluorspar and uranium (Whelan, 1965; Lindsey and Osmonson, 1978). A pluton containing a molybdenum porphyry ore deposit underlies the district (Wall Street Journal, January 8, 1978; Shawe and others, 1978).

The southern Mountain Home Range to the west not only contains abundant pre-Needles Range volcanic rocks as described above, but also a thick younger, apparently post-Needles Range stratovolcano complex north of Modena. The Indian Peak mining district in the southern Mountain Home Range has produced fluorspar from Needles Range Formation and other volcanic rocks that were intruded by quartz diorite and granodiorite stocks (Thurston and others, 1954; Bul- lock, 1976). Thick volcanic rocks in the Stateline district, which formerly produced gold and silver from veins, include rhyolite and overlie a unit whose description resembles that of Needles Range Formation (Butler and others, 1920; Thomson and Perry, 1975).

Volcanic accumulations and related plutons also occur along the Delamar-Iron Springs igneous belt (fig. 1). At the eastern end of the belt, 20-m.y.-old quartz monzonite porphyry laccoliths in the Iron Springs district (Mackin, 1960, 1968; Rowley and Barker, 1978) and Pine Valley Mountains (Cook, 1957) were emplaced in Mesozoic and Cenozoic sedimentary strata. Three of the laccoliths in the Iron Springs district were the source of major hematite and magnetite replacement orebodies in the adjacent Carmel Formation (Jurassic). Thin layers of dacitic to andesitic mudflow breccia, either derived locally or coming from centers in the Pine Valley Mountains to the south, are interlayered at several horizons within an overlying sequence of ash-flow tuffs. In the Pine Valley Mountains, locally derived sequences of latitic and andesitic lava flows, ash-flow tuff, and volcanic mudflow breccia, at least $1,400 \mathrm{~m}$ thick, have been placed in several named formations by Cook (1957).

The geology of the eastern Bull Valley Mountains is known through the mapping of Blank (1959), Blank and McKee (1969), Cook (1960a), McCarthy (1959), and Wiley (1963); but the western part, extending to the Nevada border, is poorly known and is shown by Cook (1960a, maps 1, 2, and 8) only as undifferentiated Tertiary volcanic rocks. The eastern Bull Valley Mountains contain numerous eruptive centers, the oldest of which produced andesitic lava flows and flow breccia, as much as $400 \mathrm{~m}$ thick, that lie between ash-flow tuffs dated as 22 to 21 m.y. old (Blank, 1959). Blank showed that ash-flow tuffs and lava flows of the overlying Rencher Formation (discussed in next section) came from an eruptive complex whose core now is marked by several quartz monzonite porphyry plutons, including the Bull Valley intrusion. These intrusions have been prospected for iron ore, and in many aspects they resemble intrusions of the Iron Springs district (Wells, 1938; Tobey, 1976). The Mineral Mountain pluton, farther west in the Bull Valley Mountains, may be related to this same pluton belt (Cook, 1960a). Above the Rencher Formation in the Bull Valley Mountains, locally derived andesitic volcanic breccia and lava flows, as much as $180 \mathrm{~m}$ thick, are overlain by regional and locally derived ash-flow tuff, airfall tuff, basaltic lava flows, and volcanic sedimentary rocks of the 700-m-thick Cove Mountain Formation of Cook (1960a) and Blank (1959).

\section{ASH-FLOW TUFF PROVINCE OF SOUTHWESTERN UTAH}

From about 26 m.y. ago to about 19 m.y. ago or less, much of southwestern Utah was a broad plain covered 
by thin regional silicic calc-alkalic ash-flow sheets derived from sources in the Basin and Range province. This plain was surmounted by contemporaneous intermediate-composition stratovolcanoes that were concentrated along the east-northeast-trending Pioche-Marysvale and the Delamar-Iron Springs igneous belts. The sheets intertongued with and pinched out against thick lava flows and volcanic breccia of the stratovolcanoes. None of the regional sheets was as extensive as the Needles Range Formation, which formed a flat base over which most of the younger sheets spread. Mackin (1960) was the first to recognize the pyroclastic origin of these sheets, and he applied most of the original names to them, used later in this section. Their outcrop areas are shown by Cook (1965), Williams (1967), and Rowley, Anderson, and others (1978a). Mackin (1960), Anderson and Rowley (1975), and Rowley and Barker (1978) described the tuffs; and Armstrong (1970), Fleck, Anderson, and Rowley (1975), and E. H. McKee (in Hausel and Nash, 1977, fig. 2) determined their radiometric ages. The following discussion summarizes data from all these sources.

The Isom Formation, about 26-25 m.y. old, consists of densely welded crystal-poor ash-flow tuff, lava flows, and tuff lava that commonly show secondary flow characteristics. The formation generally does not exceed $20 \mathrm{~m}$ in thickness except in the western Iron Springs district, where the formation locally is more than $250 \mathrm{~m}$ thick. The source of the formation may be located in the western part of the district or the adjacent Escalante Desert. In most places the Isom Formation rests on the Needles Range Formation. From base to top the Isom consists of the Blue Meadows, Baldhills, and Hole-In-The-Wall Tuff Members; the Baldhills Member is the most widespread.

The Quichapa Group (Williams, 1967; Anderson and Rowley, 1975) overlies the Isom Formation and consists, from base to top, of the Leach Canyon Formation, Condor Canyon Formation, and Harmony Hills Tuff. The Leach Canyon Formation consists mostly of crystal-poor ash-flow tuff rich in lithic and cognate fragments that thickens westward to more than $250 \mathrm{~m}$ in its possible source area near Caliente, Nev. (Williams, 1967). It consists of the widespread Narrows Tuff Member, about 24 m.y. old, and the overlying less widespread Table Butte Tuff Member. The Condor Canyon Formation consists of two crystal-poor ash-flow tuffs, the Swett Tuff Member (about $23 \mathrm{~m} . \mathrm{y}$. old) and the overlying Bauers Tuff Member (about 22 m.y. old). The Condor Canyon Formation units thicken westward to a combined total of more than $150 \mathrm{~m}$ near Caliente, their possible source area. The Harmony Hills Tuff, about 21 m.y. old, consists of crystal-rich ash-flow tuff that thickens to about $150 \mathrm{~m}$ in the eastern Bull Valley Mountains. Blank (1959) suggested that its source area was in the eastern Bull Valley Mountains, but more recent work indicates that it is of similar or greater thickness in the southern Clover Mountains of Nevada and may have its source in the southern part of the Caliente cauldron complex (Noble and others, 1968; Noble and McKee, 1972; Ekren and others, 1977).

Two other regional ash-flow tuffs occur stratigraphically above the Harmony Hills Tuff in the Iron Springs district, Pine Valley Mountains, Bull Valley Mountains, and southeastern Nevada. The Rencher Formation, herein adopted, was named by Cook (1957) for an ash-flow tuff and related lava flows about $180 \mathrm{~m}$ thick in the northwestern Pine Valley Mountains; Blank (1959) found that the formation is as much as $300 \mathrm{~m}$ thick in the eastern Bull Valley Mountains and, as noted above, that this was the source area. The overlying Page Ranch Formation was defined by Cook (1957) for exposures northwest of Page Ranch, just south of the Iron Springs district. Cook included within the formation a silicic, crystal-poor ash-flow tuff of significant areal extent, which Mackin (1960) called the Kane Point Tuff Member. This tuff, with an isotopic age of 19 m.y. and a thickness of as much as $180 \mathrm{~m}$, overlies fanglomerate in its type area (Mackin, 1960) and intertongues with locally derived volcanic rocks farther to the south (Cook, 1957). Blank (1959) and Cook (1960a) correlated the Kane Point Member with Blank's Racer Canyon Tuff Member of the Cove Mountain Formation. The type area of the latter member is Racer Canyon in the northeastern Bull Valley Mountains. In later reports the name Racer Canyon Tuff has been used (Noble and others, 1968; Noble and McKee, 1972; Ekren and others, 1977) at the formation rank, and it has received $\mathrm{K}$-Ar ages of 18.2 and 20.3 m.y. (Noble and McKee, 1972). It is herein adopted at the formation rank as Racer Canyon Tuff. Kane Point Tuff Member is herein abandoned in favor of the Racer Canyon Tuff, and Page Ranch Formation is herein adopted but restricted to the rocks below the Racer Canyon Tuff in the Page Ranch type area. The source of the Racer Canyon Tuff probably is the Caliente cauldron complex (Noble and others, 1968; Noble and McKee, 1972; Ekren and others, 1977). Other unnamed local ash-flow sheets exist in southwestern Utah, but their distributions and sources are poorly known.

\section{UPPER CENOZOIC SEDIMENTARY AND VOLCANIC SEQUENCE}

Extensional tectonism beginning about 20 m.y. ago, affected the Basin and Range and High Plateaus areas throughout later Cenozoic time. Warping and normal faulting divided the areas into upthrown and downthrown blocks, such that the higher areas were subject to erosion and the lower areas became sites of sedimentation. Early-formed sedimentary rocks were deformed by the continuing tectonism. 
Episodic volcanic activity accompanied the deformation and sedimentation, and a bimodal assemblage of basalt lava flows and high-silica alkali rhyolite lava flows, domes, and pyroclastic rocks was erupted from about $21 \mathrm{~m}$.y. ago to Quaternary time. The basalt flows are very widespread, although generally of low volume. The rhyolitic rocks formed around more restricted centers and range in volume from minor flows to major composite accumulations.

\section{BASIN-FILL SEDIMENTARY ROCKS}

The grabens and other structural valleys in most parts of south western Utah contain well-consolidated to poorly consolidated continental sediments of late Cenozoic age. The sediments are largely coarse- to fine-grained clastic fluvial rocks, but lacustrine rocks and airfall tuffs occur locally and are especially prominent in some valleys.

The High Plateaus subprovince has had similar geomorphic history throughout its extent. Drainage within this area is fairly well integrated, and erosion has cut deeply into the basin-fill sediments in many places; thus a composite outline of late Cenozoic history can be pieced together. The sediments, at least $350 \mathrm{~m}$ thick in some basins, were named Sevier River Formation by Callaghan (1938), who recognized that these rocks were derived from erosion of upthrown blocks and deposited in downthrown areas during late Cenozoic block faulting. Anderson and Rowley (1975) described the lithology and distribution of these rocks in the southern High Plateaus and suggested that the name Sevier River Formation be used throughout the province in preference to local terms such as Parunuweap Formation, a name that was abandoned by Anderson and Rowley (1975).

The age of the Sevier River Formation varies from basin to basin depending on the local structural history. The Sevier River Formation overlies the Joe Lott Tuff Member (19 m.y.) of the Mount Belknap Volcanics along the northern side of the Tushar Mountains, where Steven and others $(1977,1979)$ obtained fission-track ages on two tuff beds in the formation: $13.8 \mathrm{~m}$.y. for one bed near the base and 6.9 m.y. for one near the eroded top of the formation. South of Marysvale the formation is overlain by a basalt lava flow that was dated by the K-Ar method (Damon, 1969) as 12.6 m.y. old. We believe that elsewhere the Sevier River Formation may be locally as old as $20 \mathrm{~m}$.y. and as young as early Pleistocene.

In the Basin and Range province, the grabens are much more extensive than the horsts, and each appears to have had a different structural and depositional history. The present drainage system appears to have formed very recently, probably in Pleistocene time.
Downcutting is much less than in the High Plateaus, and the deposits, which locally are $1,000 \mathrm{~m}$ or more thick, are largely covered by veneers of upper Quaternary sediments. The scattered exposures of basin-fill sediments in southwestern Utah now are given numerous informal names and locally have been correlated with the Sevier River Formation or Muddy Creek Formation of Nevada. Although they commonly resemble those of the Sevier River Formation, the different histories of each basin combined with the presently fragmentary character of our data make it inadvisable to extend the term Sevier River Formation throughout southwestern Utah. We prefer to treat all these deposits in the Basin and Range province informally as basin-fill deposits.

In the Basin and Range province, the lower parts of the basin-fill deposits are exposed only where their lateral edges lap up against the ranges. Along one such outcrop in the southern Black Mountains (Rowley, 1975, 1976), basaltic lava flows that intertongue with the lower part of a basin-fill deposit have been dated (K-Ar) as 8.8 and 9.6 m.y. old (Anderson and Mehnert, 1979). Near Cove Fort, west of the southern Pavant Range, Best, McKee, and Damon (1979) have given ages of 7.4 and $9.2 \mathrm{~m} . \mathrm{y}$. for basalts interbedded with lower parts of the basin-fill deposits. The base of the deposits in deeper basins cannot be dated, but in some places they probably are much older, possibly as much as 20 m.y.

The upper parts of the basin-fill deposits in the Basin and Range province can locally be demonstrated to be quite young. In the basin north of Beaver, where the upper part of the basin fill is well exposed (Anderson and others, 1978), numerous tuff beds have been demonstrated to be latest Pliocene and Pleistocene in age (unpub. data supplied by R. E. Anderson, M. M. Machette, G. A. Izett, and H. H. Sturr, 1978, and used with permission).

\section{BIMODAL VOLCANIC ROCKS}

Upper Cenozonic basalt and alkali rhyolite cones, lava flows, domes, and tuff beds are more widespread in southwestern Utah then elsewhere in the State. They do not, however, approach the volumes of the older calc-alkalic volcanic rocks previously discussed. The bimodal rocks were erupted concurrently with deposition of the Sevier River Formation and other basin-fill deposits, and the two assemblages are interlayered in many places. The basalt commonly forms low-volume flows that are widely distributed. Only in the Black Rock Desert area west of Cove Fort do they compose sizeable volcanoes. The rhyolitic accumulations, on the other hand, tend to be more localized around restricted source areas, where they range from small local piles to 
large composite accumulations of flow and pyroclastic material. Bimodal rocks are important economically, for they localize geothermal resources and sulfur deposits. Metallic mineral deposits, generally of lithophile elements such as uranium, molybdenum, beryllium, fluorine, and tungsten, are commonly found in or near the rhyolites.

Data pertaining to lithology, chemistry, ages, and distribution of basalt in southwestern Utah have been discussed by numerous workers, including Leeman and Rogers (1970), Best and Brimhall (1970, 1974), Condie and Barsky (1972), Hoover (1974), Anderson and Rowley (1975), Stewart, Moore, and Zietz (1977), Clark (1977), and Best, McKee, and Damon (1979). Many, but far from all, basalts occur along the Basin and Range-Colorado Plateaus province boundary (Best and others, 1979). Most basalts in southwestern Utah are less than $7 \mathrm{~m}$.y. old, but in addition to older ages already mentioned, Best, McKee, and Damon (1979) have dated 10 more basalts in Utah, the oldest of which is a 13.3-m.y.-old flow west of Milford. Basalts less than 2 m.y. old are concentrated in the Black Rock Desert and in a belt lying between St. George, Cedar City, and Panguitch.

Olivine-bearing lava flows that in some places have identical field appearances to basalts have been dated stratigraphically at between 22 and 19 m.y. and by K-Ar methods at 21.1 m.y. (Best and others, 1979) in the Piute Reservoir area of the central Sevier Plateau (Rowley and others, 1979). Chemical analyses of the flow dated by K-Ar methods indicates, however, that it is not a true basalt (Wender and Nash, 1979; Best and others, 1979). These flows, at least some of which exhibit calcalkalic affinities, may mark the earliest products of the late Cenozoic basaltic volcanism.

Alkali rhyolite centers are most abundant along the Pioche-Marysvale igneous belt, where they occur discontinuously from near the Nevada-Utah line on the west to the vicinity of Marysvale on the east. The largest accumulation along this trend is the Mount Belknap Volcanics on the top of the Marysvale volcanic field (Steven and others, 1977, 1979; Cunningham and Steven, 1977, 1979a). The Mount Belknap Volcanics consists of a complex assemblage of lava flows, volcanic domes, and associated breccias and ash-flow tuffs that were erupted from two concurrently active source areas 21- 16 m.y. ago. Activity began near the northeastern end of the eastern source area, in the Antelope Range, about $21 \mathrm{~m} . \mathrm{y}$. ago with extrusion of a series of flow domes. Eruptive centers migrated southwestward over the next 4 m.y., leaving behind a complex of flows, domes, and ash-flow tuffs underlain by intrusive feeders. The largest ash-flow tuff unit was erupted about 19 m.y. ago from the middle of the eastern source area, and the small Red Hills caldera subsided at the vent area (Cunningham and Steven, 1977, 1979a). A stock of fine-grained granite, related to the Mount Belknap Volcanics, was intruded about 20 m.y. ago into an older calc-alkalinc quartz monzonite pluton in the southern Antelope Range (Cunningham and Steven, 1978a). At the western source area, on the crest of the Tushar Mountains, the major Mount Belknap caldera subsided about 19 m.y. ago in response to eruption of the Joe Lott Tuff Member of the Mount Belknap Volcanics. The caldera was filled almost immediately by comagmatic lava flows and ash-flow tuffs. The products of the eastern and western source areas complexly intertongue in the area between the sources.

Uranium-bearing veins, formed sometime between 18 and $10 \mathrm{~m} . \mathrm{y}$. ago (Cunningham and Steven, 1978a, 1979a), have been mined periodically in the Central Mining Area of the Antelope Range since 1949 (Kerr and others, 1957; Kerr, 1968). A local stock, possibly mineralized with molybdenum, has been postulated to underlie the district (Cunningham and Steven, 1978a). Alunite of similar age also has been mined in the Marysvale area. Deposits of uranium, molybdenum, and related elements may be related to the Mount Belknap caldera (Cunningham and Steven, 1979b). A 14-m.y.-old stock, possibly mineralized, is believed to underlie Alunite Ridge in the east-central Tushar Mountains (Cunningham and others, 1978). The Deer Trail mine along the eastern base of the Tushar Mountains has long produced lead-zinc-copper ore from a zone marginal to the postulated stock (Cunningham and others, 1978).

Elsewhere in the Pioche-Marysvale igneous belt, a string of rhyolite centers occurs along the east-trending Blue Ribbon lineament (Rowley, Lipman, and others, 1978) from the southern Mountain Home Range eastward to the Sevier Plateau. Five isotopic ages (Mehnert and others, 1978) indicate that the centers are younger toward the east, from a 20.2-m.y.-old rhyolite at the Staats mine, southern Wah Wah Mountains (Lindsey and Osmonson, 1978), to a 4.7-m.y.-old center at Phonolite Hill, southern Sevier Plateau (H. H. Mehnert, written commun., 1978). Rhyolite also occurs on the lineament in the southern Mountain Home Range (Thurston and others, 1954), not far from fluorspar deposits of the Indian Peak mining district, as well as in the Shauntie Hills to the east and at several places in the northern Black Mountains (Rowley, Lipman, and others, 1978).

In other parts of the Pioche-Marysvale belt, the 0.8 - to 0.5-m.y.-old rhyolite of the Mineral Mountains (Lipman and others, 1978) unconformably overlies the Mineral Mountains batholith and seems genetically related to the nearby Roosevelt Hot Springs area. Upper Cenozoic 
rhyolite centers also occur west and north of the Mineral Mountains (Mehnert and others, 1978) and east of the Mineral Mountains (Haugh, 1978). Rhyolite also is exposed at several places in the hills south of the San Francisco Mountains (P. L. Williams, oral commun., 1976), in the Stateline mining district (Butler and others, 1920), and in parts of the southern Mountain Home Range (D. A. Lindsey and D. R. Shawe, oral commun., 1975).

Rhyolitic rocks also occur in the Delamar-Iron Springs igneous belt. Cook (1957) described a small rhyodacitic lava flow of Pleistocene(?) age, which he called the Eight Mile Dacite, in the northeastern Pine Valley Mountains; Hausel and Nash (1977) gave a chemical analysis of this rock. Blank (1959) mapped a rhyolitic ash-flow sheet as much as $120 \mathrm{~m}$ thick, the Ox Valley Tuff, throughout the Bull Valley Mountains. It was named for exposures overlooking Ox Valley in the northeastern Bull Valley Mountains, and the name was formalized by Cook (1960a) and Noble and McKee (1972). This tuff, also herein adopted, has received K-Ar ages of 12.3 and 15.1 m.y., and probably was derived from the Caliente cauldron complex (Noble and McKee, 1972; Ekren and others, 1977). The tuff is overlain by rhyolite and rhyodacite lava flows, as much as $370 \mathrm{~m}$ thick, that may be derived from the Flattop Mountain area of the northeastern Bull Valley Mountains (Blank, 1959). Obsidian clasts occur in stream gravels adjacent to Modena (Umshler, 1975), but bedrock sources, presumably not far away, have not been discovered. Just west, in Nevada, abundant young rhyolites have been mapped by Stewart and Carlson (1974) and Ekren and others (1977).

\section{STRUCTURAL GEOLOGY}

Cenozoic rocks in southwestern Utah accumulated during three successive structural regimes that generally correspond to the three rock sequences. Thrust faulting and folding during the Sevier orogeny in Late Cretaceous time and warping during the Laramide orogeny in latest Cretaceous and early Tertiary time left a topographic legacy of mountains to the west bordered by basins to the east. Calc-alkalic igneous activity in middle Tertiary time was concentrated along eastnortheast-trending belts, probably structurally controlled, within which more local east-trending lineaments have been recognized; some early high-angle faulting took place concurrently and may have marked the beginning of Basin and Range-Colorado Plateaus differentiation. The late Cenozoic was the time of regional block faulting, with continued igneous activity, partly along the east-trending lineaments.

\section{OLDER STRUCTURES}

Eastward-directed thrust faults and related folds of the Sevier orogeny (Armstrong, 1968) have affected the pre-Cenozoic rocks of the Basin and Range province and the western High Plateaus area of southwestern Utah (Burchfiel and Hickcox, 1972; Crosby, 1973). The thrusts form a sinuous belt whose eastern edge (fig. 1) extends northwest across the Basin and Range province of southwestern Utah to intersect the High Plateaus north of Cove Fort. Northeast- or north-northeaststriking overturned and open folds, locally thrust faulted, form a parallel belt to the southeast, where they mark the leading edge of the Sevier disturbed belt. One such fold, extending from the eastern Bull Valley Mountains through Iron Springs and the Red Hills, later localized at least a half dozen iron-bearing plutons (Mackin, 1960; Threet, 1963b; Tobey, 1976). Other related folds include the Virgin anticline-Kanarra fold, which extends from east of St. George north past Cedar City (Threet, 1963a; Averitt, 1962; Kurie, 1966), and minor warps in the High Plateaus farther east (Stokes and Heylmun, 1963, fig. 2).

Armstrong (1968) considered the Sevier orogeny to be mostly Cretaceous, but in the eastern Bull Valley Mountains (Wiley, 1963), related thrusting and folding may have extended into early Tertiary time, and in the Pavant Range and areas to the north, folding and local thrusting continued into Paleocene time (Stanley and Collinson, 1979). The highlands resulting from the Sevier orogeny shed much clastic material into adjacent basins to form the uppermost Cretaceous(?) and lower Tertiary sedimentary sequence of southwestern Utah. Highlands were most pronounced along the western edge of the State, and here they apparently have never been covered by a significant thickness of lower Tertiary sedimentary rocks.

The Colorado Plateaus area of southwestern Utah was locally warped in Late Cretaceous and early Tertiary time, and we ascribe this deformation to the Laramide orogeny. The highlands that formed shed a significant amount of the clastic sediment of the lower Tertiary sedimentary sequence; some of this sediment may have come from the Arizona part of the Colorado Plateaus province (Young and McKee, 1978). The Circle Cliffs upwarp, southeast of the High Plateaus, may have remained a highland until eruption of the Needles Range Formation (Rowley, 1968). The Laramide orogeny may also have created the two basins that contain the Claron Formation and the North Horn through Crazy Hollow Formations, along with the intervening Tushar highland, discussed earlier. 


\section{EAST-TRENDING FEATURES}

The Pioche-Marysvale and Delamar-Iron Springs igneous belts extend east-northeast across southern Utah and probably are structurally controlled. The coincidence of mineral deposits within these belts has been recognized since the time of Butler and others (1920), and it has been described in greater detail by Hilpert and Roberts (1964), Stacey, Zartman, and NKomo (1968), Shawe and Stewart (1976), and Rowley and others (1978a). These belts contain most of the known volcanic centers, plutons, hot springs, igneousrelated mineralized rocks, and hydrothermally altered rocks in southwestern Utah; they also contain virtually all the known east-striking faults. Stewart, Moore, and Zietz (1977) noted that the calc-alkalic rocks in igneous belts of western Utah are younger from north to south. Igneous rocks of the Pioche-Marysvale igneous belt seem to be generally older than those of the DelamarIron Springs belt, tending further to support this hypothesis.

Several east-trending lineaments (fig. 1), defined by an alinement of topographic features, faults, magnetic anomalies, volcanic centers, plutons, hot springs, and mineralized and hydrothermally altered rocks, have been identified within the igneous belts. Ekren and others (1976) defined the Timpahute lineament from features that extend from west of the Tempiute mining district in southeastern Nevada eastward to just east of the State line. It may extend along the northern side of the Delamar-Iron Springs igneous belt as far east as Cedar City.

Rowley, Lipman, and others (1978) defined the Blue Ribbon lineament as a feature about $25 \mathrm{~km}$ wide and $360 \mathrm{~km}$ long that extends from the central Sevier Plateau westward into Nevada, where it connects with the 230-km-long Warm Springs lineament of Ekren and others (1976). The Blue Ribbon lineament crosses the Pioche-Marysvale igneous belt at a low angle; it begins on the east along the southern side of the igneous belt, is about in the middle of the belt at the Nevada-Utah State line, and is along the northern side of the belt farther west in Nevada. Some faults along the Warm Springs lineament in Nevada have had strike-slip displacement, but predominant movement along the eaststriking faults on the Blue Ribbon lineament seems to have been dip slip. Within southwestern Utah, eaststriking faults are progressively less common eastward along the lineament, and alkalic rhyolite centers tend to be younger eastward. Igneous activity and faulting along the lineament range in age from at least $26 \mathrm{~m}$.y. to the present, concurrent with both calc-alkalic magmatism and basin-range faulting.
The northern side of the Pioche-Marysvale igneous belt is partly defined by an obscure lineament that extends from the Sevier Plateau at least as far west as the northern Mineral Mountains and, based on aeromagnetic anomalies, perhaps $50 \mathrm{~km}$ or more farther west (fig. 1). Crosby (1973) called the lineament the Black Rock offset zone and suggested that strikeslip faulting was important along it; this suggestion has yet to be substantiated, however. G. L. Galyardt (oral commun., 1976), T. A. Steven (unpub. data, 1977), and Rowley, Lipman, and others (1978) also noted various geologic features along the trend of the Black Rock lineament, which is defined by a downwarp along Clear Creek on the northern flank of the Tushar highland, by aeromagnetic and other geophysical anomalies, by dipslip and strike-slip(?) faults, by volcanic centers, by sulfur occurrences and hot springs, and by the abrupt northward termination of the Marysvale volcanic pile. It spans an age from at least $27 \mathrm{~m} . \mathrm{y}$. to the present.

\section{BASIN-RANGE FAULTS}

Most of the present topography of the Basin and Range province and the High Plateaus of southwestern Utah is due to basin-range block faulting. Topographic scarps of $1,000 \mathrm{~m}$ or more are common, and in order to produce some of the deep grabens (Cook and Hardman, 1967), relative movement on some faults must have been at least several times this amount. The Mineral Mountains seems to be the highest upthrown block in southwestern Utah; it stands higher structurally than the Colorado Plateaus to the east of it. Basin-range deformation included some warping as well as faulting, as evidenced by the Wasatch monocline in the northeastern High Plateaus and a monocline north of Cedar City (Threet, 1963a; Averitt and Threet, 1973).

Faults are abundant in the Basin and Range province, where the basins occupy more area than the ranges. In the High Plateaus, on the other hand, faults appear to be less abundant and to have less displacement, and the upthrown blocks seem to have greater area than the downthrown blocks. Range-margin faults predominate in the High Plateaus, and the main parts of the upthrown blocks are cut by relatively few faults. The abundance of faults and the amount of displacement decrease eastward across the High Plateaus to the edge of the nearly unfaulted main body of the Colorado Plateaus province.

Most basin-range faults fall into two sets, one of which strikes north-northeast and the other northnorthwest, and the trends of the basins and ranges depend on which set predominates in any given area. Generally speaking, the north-northeast-trending set 
predominates in southwestern Utah. The faults in most places occur in zones rather than as single isolated planes, and within these zones the fractures form four main patterns: parallel, en echelon, rhombic, and zigzag. Parallel faults characterize most zones. Commonly the faults in such a zone all have the same sense of displacement, producing a step pattern of offset; most of the offset across such a zone is across one or a very few predominant faults within the zone. The blocks between the faults are commonly tilted in the direction opposite that of the fault, forming antithetic tilt blocks that reduce the apparent overall displacement on the faults. In some places, as in the Markagunt Plateau (Anderson, 1965), faults in a parallel zone dip in opposite directions, giving rise to horsts and grabens.

Zones of en echelon faults, most of whose individual faults dip in the same direction, are common in some places; an example is the Sevier fault zone, which defines the western edge of the Sevier Plateau (Rowley, 1968). The origin of some en enchelon fault zones has been ascribed to wrench faulting in basement rocks, but in southwestern Utah no evidence for a wrench-fault origin has been found.

Fault patterns characterized by rhombic-shaped blocks are generally produced by north-northeast and north-northwest-trending fault zones intersecting at angles of about $60^{\circ}$ and $120^{\circ}$. Such patterns are common in southwestern Utah. They resemble in form the pattern described by Donath (1962) in southern Oregon, but in southwestern Utah they are well developed only in small scattered areas and are poorly explained by wrench-fault stress fields. These patterns appear to occur in exceptionally stressed areas and to have resulted from torsional deformation between major fault blocks or in zones within major blocks that have been twisted in different directions. Several rhombic sets lie along the Blue Ribbon lineament, including a major set northeast of Circleville on the western side of the central Sevier Plateau, and other sets lie along the easttrending scarp between the northern Markagunt Plateau and southern Tushar Mountains. A rhombic set in the Antelope Range-Sevier area lies at least partly on the Black Rock lineament. Rhombic patterns, which indicate areas that have been subject to greater tectonic stress, may localize igneous activity and mineralization; the Central Mining Area of the Marysvale district occurs in such an area (Cunningham and Steven, 1978a).

A zigzag fault pattern reflects an interplay of the same north-northeast- and north-northwest-striking fault sets responsible for the trends of mountains and basins, for rhombic fault patterns, and for minor features along individual faults. Hamblin (1970) and Best and Hamblin $(1970,1978)$ have observed zigzag pat- terns at all scales along the Hurricane fault zone. The Sevier, Tushar, and Indian Hollow fault zones (Molloy and Kerr, 1962), bounding respectively the western Sevier Plateau, eastern Tushar Mountains, and eastern Pavant Range, have an overall zigzag map pattern.

Basin-range faulting can be dated by determining the radiometric age of the rocks involved. By this method, faulting is known to have begun in earliest Miocene time and to have extended to the Holocene. The largest displacements, however, seem to have taken place after 7 m.y. ago.

The oldest faulting possibly related to basin-range tectonism took place somewhat before eruption of the Osiris Tuff, 22 m.y. ago. Pre- Osiris high-angle faulting in the southern High Plateaus has been noted by J. J. Anderson (1965, 1971), Rowley (1968), and Rowley, Anderson, and others (1978a), and in the Cove Fort area by T. A. Steven (unpub. data, 1978). Near Cove Fort, this faulting clearly followed eruption of the Three Creeks Tuff Member, 27 m.y. ago. Whereas some of this faulting may be ancestral to the main basin-range breakup later, some or all may have resulted from deformation along the east-northeast-trending igneous belts. Clearly, however, the widespread presence of the Osiris Tuff throughout the Marysvale field (fig. 4) indicates that true basin-range topography had not started to form by this time. Similarly, there is no evidence that the tuffs, as young as 19 m.y. old, of the ash-flow tuff field of southwestern Utah erupted onto basin-range topography.

From about 20 m.y. ago to 7 m.y. ago, the High Plateaus and perhaps other parts of southwestern Utah as well may have been characterized by broad warping as much as or more than by faulting. The developing basins received continental sediments of the Sevier River Formation in the High Plateaus and basin-fill sediments in the Basin and Range province. The character and age of the deformation, unfortunately, is difficult to document conclusively.

Major faulting in the Clear Creek area between the Pavant Range and Tushar Mountains took place after 7 m.y. ago, the fission-track age obtained from a tuff bed near the top of the Sevier River Formation near Sevier, Utah (Steven and others, 1977). The basin itself, however, had been in existence at least by $14 \mathrm{~m} . \mathrm{y}$. ago, the fission-track age from a tuff bed near the base of the Sevier River Formation west of Sevier (Steven and others, 1977, 1979). A basin west of the Pine Valley Mountains appears to have started to subside about 8 m.y. ago (Anderson and Mehnert, 1979). Elsewhere in southwestern Utah, the age of major faulting seems to have been younger than 10 m.y. based on offsets of dated basalt flows. Anderson and Mehnert (1979) believed 
that most faulting along the Hurricane fault zone is Quaternary, and Pleistocene faults are abundant elsewhere in southwestern Utah.

Holocene faults occur locally (Anderson, 1978), and Anderson and Bucknam (1979) discovered a $800 \mathrm{~km}^{2}$ area near Enterprise in the southern Escalante Desert that has experienced uplift of at least $30 \mathrm{~m}$, probably in Holocene time. Faulting is still active in the area. The axis of the intermountain seismic belt (Smith and Sbar, 1974 ) runs south along the Wasatch front, apparently into Arizona (Anderson, 1978). The southern Nevada seismic belt, bearing east across southern Nevada, enters Utah and swings northeast to intersect the intermountain seismic belt near Cedar City.

\section{LOW-ANGLE TERTIARY FAULTS}

Low-angle Tertiary faults of two types are known in southwestern Utah. The first consists of large slide blocks derived from oversteepened flanks of domes lifted by rapidly emplaced shallow intrusions. The spectacular slides on the eastern flank of Iron Mountain laccolith in the Iron Springs district (Mackin, 1960; Blank and Mackin, 1967; J. H. Mackin and P. D. Rowley, unpub. data, 1976) involved rocks as young as the Harmony Hills Tuff. Individual slide blocks, more than $4 \mathrm{~km}$ long, moved eastward as much as $2 \mathrm{~km}$ on subhorizontal, concave-upward, spoon-shaped surfaces. Radiometric ages on the laccolith, and thus the age of the slide blocks, are about 20 m.y. (Armstrong, 1970). Blank (1959) and Cook (1960a) discussed similar structures of the same general age in the Pine Valley and Bull Valley Mountains.

The second type of low-angle Tertiary structure is denudation faults (or distension or attenuation faults) that moved on low-angle normal fault planes (Anderson, 1971; Armstrong, 1972). The denudation faults represent extension off the shoulders of uplifted basin ranges, or represent the low parts of listric faults now exposed by deep erosion following major uplift of the range. The Tertiary gravity slide blocks studied by Dobbin (1939), Cook (1960a, b), and Jones (1963) in the Beaver Dam Mountains may be denudation faults. Nielson and others (1978) mapped low-angle normal faults cutting the batholith of the Mineral Mountains, and these too may be denudation faults.

\section{THE COLORADO PLATEAUS}

The Basin and Range-Colorado Plateaus province boundary follows an important structural hingeline that has been active since early Paleozoic or even late
Precambrian time (Hunt, 1956; Gilluly, 1963; Hintze, 1973). This hinge line has had major influence on eastwest sedimentary facies changes throughout this time. The present Basin and Range and Colorado Plateaus provinces separated structurally in middle to late Cenozoic time, after deposition of the Needles Range Formation 30-29 m.y. ago (Rowley, Anderson, and others, 1978a). In late Cenozoic time, after 10 m.y. ago, both provinces underwent major uplift with respect to sea level, and they assumed their present high structural level (Best and Hamblin, 1978).

The beginning of structural separation of the Basin and Range and Colorado Plateaus provinces is believed to be chronicled by the distribution of ash-flow tuffs belonging to the calc-alkalic volcanic assemblage (Rowley, Anderson, and others, 1978a). The Isom Formation (26-25 m.y.) and the different formations in the Quichapa Group (24-21 m.y.) are widespread throughout much of the Basin and Range province of southwestern Utah, but then terminate near the present western edge of the High Plateaus. The termination of the tuffs is interpreted to be due to topographic scarps that existed at different times and different places within a 10to $20-\mathrm{km}$-wide ancestral boundary zone. Anderson and Mehnert (1979) have criticized this idea of an ancestral boundary largely because of their observation of similar thicknesses of tuffs across a small area now occupied by the Cedar City-Parowan monocline and because of the fact that no alluvial sediments have not been found between the volcanic units near the boundary zone. However, the Cedar City-Parowan monocline probably formed largely west of, and much later than, the ancestral boundary. The specific cause of the inferred scarps in the ancestral boundary zone is not known, but either high-angle faulting or gentle warping would account for uplift to the east. The difference in relief between the two provinces at this old age could have been as low as 30-100 m, or it could have been much higher. Most likely the ancestral uplift was accomplished in many episodes throughout early Miocene time, but erosion periodically lowered and modified the front. Anderson and Mehnert (1979) documented a case for Miocene or Pliocene deposition on the Kolob Terrace of coarse gravels that were derived from the Pine Valley Mountains; they probably were deposited during a period when this part of the Colorado Plateaus province was lower than the source area in the Basin and Range province.

\section{REFERENCES CITED}

Anderson, J. J., 1965, Geology of northern Markagunt Plateau, Utah: Austin, University of Texas Ph. D. thesis, 194 p. 
1971, Geology of the southwestern High Plateaus of Utah - Bear Valley Formation, an Oligocene-Miocene volcanic arenite: Geological Society of America Bulletin, v. 82, p. 1179-1205.

Anderson, J. J. and Rowley, P. D., 1975, Cenozoic stratigraphy of southwestern High Plateaus of Utah, in Anderson, J. J., Rowley, P. D., Fleck, R. J., and Nairn, A. E. M., Cenozoic geology of southwestern High Plateaus of Utah, Geological Society of America Special Paper 160, p. 1-52.

Anderson, J. J., Rowley, P. D., Fleck, R. J., and Nairn, A. E. M., 1975, Cenozoic geology of southwestern High Plateaus of Utah: Geological Society of America Special Paper 160, $88 \mathrm{p}$.

Anderson, R. E., 1971, Thin skin distension in Tertiary rocks of southeastern Nevada: Geological Society of America Bulletin, v. 82, p. $43-58$

1978, Quaternary tectonics along the Intermountain Seismic belt south of Provo, Utah: Brigham Young University Geology Studies, v. 25, pt. 1, p. 1-10.

Anderson, R. E., and Bucknam, R. C., 1979, Two areas of probable Holocene deformation in southwestern Utah: Tectonophysics, v. 52, p. 417-430.

Anderson, R. E., and Mehnert, H. H., 1979, Reinterpretation of the history of the Hurricane fault in Utah, in Newman, G. W., ed., Basin and Range Conference Guidebook: Geological Society of Nevada, Rocky Mountain Association of Geologists, and Utah Geological Association. (In press.)

Anderson, R. E., Bucknam, R. C., and Hamblin, Kenneth, 1978, Road $\log$ to the Quaternary tectonics of the Intermountain Seismic Belt between Provo and Cedar City, Utah: Geological Society of America Rocky Mountain Section Annual Meeting, Field Trip $8,50 \mathrm{p}$.

Armstrong, R. L., 1968, Sevier orogenic belt in Nevada and Utah: Geological Society of America Bulletin, v. 79, p. 429-458.

1970, Geochronology of Tertiary igneous rocks, eastern Basin and Range Province, western Utah, eastern Nevada, and vicinity, U.S.A.: Geochimica et Cosmochimica Acta, v. 34, p. 203-232.

1972, Low-angle (denudation) faults, hinterland of the Sevier orogenic belt, eastern Nevada and western Utah: Geological Society of America Bulletin, v. 83, P. 1729-1754.

Averitt, Paul, 1962, Geology and coal resources of the Cedar Mountain quadrangle, Iron County, Utah: U.S. Geological Survey Professional Paper 389, $72 \mathrm{p}$.

Averitt, Paul, and Threet, R. L., 1973, Geologic map of the Cedar City quadrangle, Iron County, Utah: U.S. Geological Survey Geologic Quadrangle Map GQ-1120.

Best, M. G., 1976, Geologic map of the Lopers Spring quadrangle, Beaver County, Utah: U.S. Geological Survey Miscellaneous Field Studies Map MF-739.

Best, M. G., and Brimhall, W. H., 1970, Late Cenozoic basalt types in the western Grand Canyon region, in Hamblin, W. K., and Best, M. G., eds., Guidebook to the geology of Utah, no. 23, The western Grand Canyon district: Utah Geological Society, p. 57-74.

1974, Late Cenozoic alkalic basaltic magmas in the western Colorado Plateaus and the Basin and Range transition zone, U.S.A., and their bearing on mantle dynamics: Geological Society of America Bulletin, v. 85, p. 1677-1690.

Best, M. G., and Hamblin, W. K., 1970, Implications of tectonism and volcanism in the western Grand Canyon, in Hamblin, W. K., and Best, M. G., eds., Guidebook to the geology of Utah, no. 23, The western Grand Canyon district: Utah Geological Society, p. $75-79$.
1978, Origin of the northern Basin and Range province Implications from the geology of its eastern boundary, in Smith, R. B., and Eaton, G. P., eds., Cenozoic tectonics and regional geophysics of the western Cordillera: Geological Society of America Memoir 152, p. 313-340.

Best, M. G., McKee, E. H., and Damon, P. E., 1979, Space-timecomposition patterns of late Cenozoic mafic volcanism, southwestern Utah: American Journal of Science. (In press.)

Best, M. G., Shuey, R. T., Caskey, C. F., and Grant, S. K., 1973, Stratigraphic relations of members of the Needles Range Formation at type localities in southwestern Utah: Geological Society of America Bulletin, v. 84, p. 3269-3278.

Blank, H. R., Jr., 1959, Geology of the Bull Valley district, Washington County, Utah: Seattle, University of Washington $\mathrm{Ph}$. D. thesis, $177 \mathrm{p}$

Blank, H. R., Jr., and Mackin, J. H., 1967, Geologic interpretation of an aeromagnetic survey of the Iron Springs district, Utah: U.S. Geological Survey Professional Paper 516-B, 14 p.

Blank, H. R., Jr., and McKee, E. H., 1969, Chemical variations and $\mathrm{K}-\mathrm{Ar}$ ages of volcanic rocks in the Bull Valley district, Utah: Geological Society of America Abstracts with Programs, 1969, pt. 3 , p. 7

Bowers, W. E., 1972, The Canaan Peak, Pine Hollow, and Wasatch Formations in the Table Cliff region, Garfield County, Utah: U.S. Geological Survey Bulletin 1331-B, 39 p.

Bullock, K. C., 1976, Fluorite occurrences in Utah: Utah Geological and Mineral Survey Bulletin 110,89 p.

Burchfiel, B. C., and Hickcox, C. W., 1972, Structural development of central Utah, in Baer, J. L., and Callaghan, Eugene, eds., Plateau- Basin and Range transition zone, central Utah, 1972: Utah Geological Association Publication 2, p. 55-66.

Bushman, A. V., 1973, Pre-Needles Range silicic volcanism, Tunnel Spring Tuff (Oligocene), west-central Utah: Brigham Young University Geology Studies, v. 20, pt. 4, p. 159-190.

Butler, B. S., 1913, Geology and ore deposits of the San Francisco and adjacent districts, Utah: U.S. Geological Survey Professional Paper 80, $212 \mathrm{p}$.

Butler, B. S., Loughlin, G. F., Heikes, V. C., and others, 1920, The ore deposits of Utah: U.S. Geological Survey Professional Paper $111,672 \mathrm{p}$.

Callaghan, Eugene, 1938, Preliminary report on the alunite deposits of the Marysvale region, Utah: U.S. Geological Survey Bulletin 886-D, p. 91-134.

1939, Volcanic sequence in the Marysvale region in southwest-central Utah: American Geophysical Union Transactions, Annual Meeting, 20th, Washington, D.C., 1939, pt. 3, p. 438-452.

1973, Mineral resources potential of Piute County, Utah and adjoining area: Utah Geological and Mineralogical Survey Bulletin $102,135 \mathrm{p}$.

Callaghan, Eugene, and Parker, R. L., 1961a, Geology of the Monroe quadrangle, Utah: U.S. Geological Survey Geologic Quadrangle Map GQ-155.

1961b, Geologic map of part of the Beaver quadrangle, Utah: U.S. Geological Survey Mineral Investigations Map MF-202. 1962a, Geology of the Delano Peak quadrangle, Utah: U.S. Geological Survey Geologic Quadrangle Map GQ-153.

$1962 b$, Geology of the Sevier quadrangle, Utah: U.S. Geological Survey Geologic Quadrangle Map GQ-156.

Campbell, D. R., 1979, Stratigraphy of pre-Needles Range Formation ash-flow tuffs in the northern Needle Range and southern Wah Wah Mountains, Beaver County, Utah: Brigham Young University Geology Studies. (In press.) 
Clark, E. E., 1977, Late Cenozoic volcanic and tectonic activity along the eastern margin of the Great Basin, in the proximity of Cove Fort, Utah: Brigham Young University Geology Studies, v. 24, pt. 1, p. 87-114.

Condie, K. C., 1960, Petrogenesis of the Mineral Range pluton, southwestern Utah: Salt Lake City, University of Utah M.S. thesis, $94 \mathrm{p}$.

Condie, K. C., and Barsky, C. K., 1972, Origin of Quaternary basalts from the Black Rock Desert region, Utah: Geological Society of America Bulletin, v. 83, p. 333-352.

Conrad, O. G., 1969, Tertiary volcanic rocks of Needles Range, western Utah: Utah Geological and Mineralogical Survey Special Studies 29, $28 \mathrm{p}$.

Cook, E. F., 1957, Geology of the Pine Valley Mountains, Utah: Utah Geological and Mineralogical Survey Bulletin 58, 111 p. 1960a, Geologic atlas of Utah - Washington County: Utah Geological and Mineralogical Survey Bulletin 70, 119 p. 1960b, Breccia blocks (Mississippian) of the Welcome Springs area, southwest Utah: Geological Society of America Bulletin, v. 71 , p. 1709-1712.

1965, Stratigraphy of Tertiary volcanic rocks in eastern Nevada: Nevada Bureau of Mines Report 11, $61 \mathrm{p}$.

Cook, K. L., and Hardman, Elwood, 1967. Regional gravity survey of the Hurricane fault area and Iron Springs district, Utah: Geological Society of America Bulletin, v. 78, p. 1063-1076.

Crosby, G. W., 1973, Regional structure in southwestern Utah, in Hintze, L. F., and Whelan, J. A., eds., Geology of the Milford area, 1973: Utah Geological Association Publication 3, p. 27-32.

Cunningham, C. G., and Steven, T. A., 1977, Mount Belknap and Red Hills calderas and associated rocks, Marysvale volcanic field, west-central Utah: U.S. Geological Survey Open-File Report 77-568, $40 \mathrm{p}$.

1978a, Postulated model of uranium occurrence in the Central Mining Area, Marysvale district, west-central Utah: U.S. Geological Survey Open-File Report 78-1093, 19 p.

1978b, Geologic map of the Delano Peak NW quadrangle, west-central Utah: U.S. Geological Survey Miscellaneous Field Studies Map MF-967.

1979a, Mount Belknap and Red Hills calderas and associated rocks, Marysvale volcanic field, west-central Utah: U.S. Geological Survey Bulletin 1468.

$1979 \mathrm{~b}$, Environments favorable for the occurrence of uranium within the Mount Belknap caldera, Beaver Valley and Sevier River Valley, west-central Utah: U.S. Geological Survey Open-File Report 79-434, $15 \mathrm{p}$.

1979c, Geologic map of the Delano Peak NE quadrangle, west-central Utah: U.S. Geological Survey Miscellaneous Field Studies Map MF-1105.

1979d, Geologic map of the Marysvale NW quadrangle, west-central Utah: U.S. Geological Survey Miscellaneous Field Studies Map MF-1106.

Cunningham, C. G., Steven, T. A., and Naeser, C. W., 1978, Preliminary structural and mineralogical analysis of the Deer Trail Mountain-Alunite Ridge mining area, Utah: U.S. Geological Survey Open-File Report 78-314.

Damon, P. E., 1968, Correlation and chronology of ore deposits and volcanic rocks: Tucson, Arizona University, Geochronology Laboratory, U.S. Atomic Energy Commission Contract AT(11-1)-689, Annual Program Report COO-689-100, 75 p.

1969, Correlation and chronology of ore deposits and volcanic rocks: Tucson, Arizona University, Geochronology Laboratory, U.S. Atomic Energy Commission Contract AT(11-1)-689, Annual Program Report COO-689-120, 90 p.
Dobbin, C. E., 1939, Geologic structure of St. George district, Washington County, Utah: American Association of Petroleum Geologists Bulletin, v. 23, p. 121-144.

Doelling, H. H., 1975, Geology and mineral resources of Garfield County, Utah: Utah Geological and Mineralogical Survey Bulletin 107, $175 \mathrm{p}$.

Donath, F. A., 1962, Analysis of basin-range structure, south-central Oregon: Geological Society of America Bulletin, v. 73, p. 1-16.

Dutton, C. E., 1880, Report on the geology of the High Plateaus of Utah with atlas: U.S. Geological Survey, Rocky Mountain Region (Powell), $307 \mathbf{p}$.

Earll, F. N., 1957, Geology of the central Mineral Range, Beaver County, Utah: Salt Lake City, University of Utah Ph. D. thesis, $112 \mathrm{p}$.

East, E. H., 1966, Structure and stratigraphy of San Francisco Mountains, western Utah: American Association of Petroleum Geologists Bulletin, v. 50, p. 901-920.

Ekren, E. B., Bucknam, R. C., Carr, W. J., Dixon, G. L., and Quinlivan, W. D., 1976, East-trending structural lineaments in central Nevada: U.S. Geological Survey Professional Paper 986, 16 p.

Ekren, E. B., Orkild, P. P., Sargent, K. A., and Dixon, G. L., 1977, Geologic map of Tertiary rocks, Lincoln County, Nevada: U.S. Geological Survey Miscellaneous Geologic Investigations Map I-1041.

Erickson, M. P., 1973, Volcanic rocks of the Milford area, Beaver County, Utah, in Hintze, L. F., and Whelan, J. A., eds., Geology of the Milford area: Utah Geological Association Publication 3, p. $13-21$.

Fleck, R. J., Anderson, J. J., and Rowley, P. D., 1975, Chronology of mid-Tertiary volcanism in High Plateaus region of Utah, in Anderson, J. J., Rowley, P. D., Fleck, R. J., and Nairn, A. E. M., Cenozoic geology of southwestern High Plateaus of Utah: Geological Society of America Special Paper 160, p. 53-62.

Fouch, T. D., 1979, Character and paleogeographic distribution of Upper Cretaceous(?) and Paleogene nonmarine sedimentary rocks in east- central Nevada, in Armentrout, J. M. Cole, M. R., and TerBest, Harry, eds., Cenozoic Paleogeography of the western United States: Society of Economic Paleontologists and Mineralogists Pacific Section. (In press).

Gilluly, James, 1963, The tectonic evolution of the western United States: Quarterly Journal of the Geological Society of London, v. 119 , p. 133-174.

Grant, T. C., 1979, Geology of the Spry intrusion, Garfield County, Utah: Kent, Ohio, Kent State University M.S. thesis, 59 p. Hall, R. B., 1978, World nonbauxite aluminum resources--alunite: U.S. Geological Survey Professional Paper 1076-A, 35 p.

Hamblin, W. K., 1970, Structure of the western Grand Canyon region, in Hamblin, W. K., and Best, M. G., eds., Guidebook to the geology of Utah, no. 23, The western Grand Canyon district: Utah Geological Society, p. 3-20

Haugh, Galen, 1978, A preliminary geologic map of the Wildcat Creek area, eastern Beaver County, Utah: Utah Geology, v. 5, p. $33-36$.

Hausel, W. D., and Nash, W. P., 1977, Petrology of Tertiary and Quaternary volcanic rocks, Washington County, south western Utah: Geological Society of America Bulletin, v. 88, p. 1831-1842.

Hilpert, L. S., and Roberts, R. J., 1964, Geology - Economic geology, in U.S. Geological Survey, Mineral and water resources of Utah: U.S. 88th Congress, 2d session, p. 28-38.

Hintze, L. F., 1963, Geologic map of southwestern Utah: Salt Lake City, Utah Geological and Mineralogical Survey.

1973, Geologic history of Utah: Brigham Young University Geology Studies, v. 20, pt. 3, p. 1-181. 
1974a, Preliminary geologic map of The Barn quadrangle, Millard County, Utah: U.S. Geological Survey Miscellaneous Field Studies Map MF-633.

1974b, Preliminary geologic map of the Crystal Peak quadrangle, Millard County, Utah: U.S. Geological Survey MisceIlaneous Field Studies Map MF-635.

1974c, Preliminary geologic map of the Wah Wah Summit quadrangle, Millard County, Utah: U.S. Geological Survey Miscellaneous Field Studies Map MF-637.

Hintze, L. F., and Whelan, J. A., eds., 1973, Geology of the Milford area, 1973: Utah Geological Association Publication 3, $94 \mathrm{p}$.

Hoover, J. D., 1974, Periodic Quaternary volcanism in the Black Rock Desert, Utah: Brigham Young University Geology Studies, v. 21, pt. 1, p. 3-72.

Hunt, C. B., 1956, Cenozoic geology of the Colorado Plateau: U.S. Geological Survey Professional Paper 279, 99 p.

Jones, R. W., 1963, Gravity structures in the Beaver Dam Mountains, southwestern Utah, in Heylmun, E. B., ed., Intermountain Association of Petroleum Geologists Guidebook to the geology of southwestern Utah, Annual Field Conference, 12th: Utah Geological and Mineralogical Survey, p. 90-95.

Kennedy, R. R., 1960, Geology between Pine (Bullion) Creek and Tenmile Creek, eastern Tushar Range, Piute County, Utah: Brigham Young University Research Studies, Geology Series, v. 7, no. 4,58 p.

1963, Geology of Piute County, Utah: Tucson, University of Arizona $\mathrm{Ph}$. D. thesis, $282 \mathrm{p}$.

Kerr, P. F., 1968, The Marysvale, Utah, uranium deposits, - Ore deposits of the United States, 1933-1967 (Graton-Sales volume), v. 2: American Institute of Mining, Metallurgical, and Petroleum Engineers, p. 1020-1042.

Kerr, P. F., Brophy, G. P., Dahl, H. M., Green, Jack, and Woolard, L. E., 1957, Marysvale, Utah, uranium area - Geology, volcanic relations, and hydrothermal alteration: Geological Society of America Special Paper 64, $212 \mathrm{p}$.

Kurie, A. E., 1966, Recurrent structural disturbance of Colorado Plateau margin near Zion National Park, Utah: Geological Society of America Bulletin, v. 77, p. 867-872.

Leeman, W. P., and Rogers, J. J. W., 1970, Late Cenozoic alkaliolivine basalts of the Basin-Range province, U.S.A.: Contributions to Mineralogy and Petrology, v. 25, p. 1-24.

Leith, C. K., and Harder, E. C., 1908, The iron ores of the Iron Springs district, southern Utah: U.S. Geological Survey Bulletin 338,102 p.

Lemmon, D. M., Silberman, M. L., and Kistler, R. W., 1973, Some $\mathrm{K}$-Ar ages of extrusive and intrusive rocks of the San Francisco and Wah Wah Mountains, Utah, in Hintze, L. F., and Whelan, J. A., eds., Geology of the Milford area: Utah Geological Association Publication 3, p. 23-26.

Liese, H. C., 1957, Geology of the northern Mineral Range, Millard and Beaver Counties, Utah: Salt Lake City, University of Utah M.S. thesis, $88 \mathrm{p}$.

Lindsey, D. A., and Osmonson, L. M., 1978, Mineral potential of altered rocks near Blawn Mountain, Wah Wah Range, Utah: U.S. Geological Survey Open-File Report 78-114, 18 p.

Lipman, P. W., Rowley, P. D., Mehnert, H. H., Evans, S. H., Jr., Nash, W. P., and Brown, F. H., 1978, Pleistocene rhyolite of the Mineral Mountains, Utah: Geothermal and archeological significance: U.S. Geological Survey Journal of Research, v. 6, p. $133-147$.

Mackin, J. H., 1960, Structural significance of Tertiary volcanic rocks in southwestern Utah: American Journal of Science, $v$. 258, p. 81-131.
1963, Reconnaissance stratigraphy of the Needles Range Formation in southwestern Utah, in Heylmun, E. B., ed., Intermountain Association of Petroleum Geologists Guidebook to the geology of southwestern Utah, Annual Field Conference, 12th: Utah Geological and Mineralogical Survey, p. 71-78.

1968 , Iron ore deposits of the Iron Springs district, southwestern Utah, in Ore deposits of the United States, 1933-1967 (Graton-Sales volume), v. 2: American Institute of Mining, Metallurgical, and Petroleum Engineers, p. 992-1019.

Mackin, J. H., and Rowley, P. D., 1975, Geologic map of the Avon SE quadrangle, Iron County, Utah: U.S. Geological Survey Geologic Quadrangle Map GQ-1294.

1976, Geologic map of The Three Peaks quadrangle, Iron County, Utah: U.S. Geological Survey Geologic Quadrangle Map GQ-1297.

Mackin, J. H., Nelson, W. H., and Rowley, P. D., 1976, Geologic map of the Cedar City NW quadrangle, Iron County, Utah: U.S. Geological Survey Geologic Quadrangle Map GQ-1295.

McCarthy, W. R., 1959, Stratigraphy and structure of the GunlockMotoqua area, Washington County, Utah: Seattle, University of Washington M.S. thesis, $41 \mathrm{p}$.

Mehnert, H. H., Rowley, P. D., and Lipman, P. W., 1978, K-Ar ages and geothermal implications of young rhyolites in west-central Utah: Isochron/West, no. 21, p. 3-7.

Miller, G. M., 1966, Structure and stratigraphy of southern part of Wah Wah Mountains, southwest Utah: American Association of Petroleum Geologists Bulletin, v. 50, p. 858-900.

Molloy, M. W., and Kerr, P. F., 1962, Tushar uranium area, Marysvale, Utah: Geological Society of America Bulletin, v. 73, p. 211-236.

Nielson, D. L., Sibbett, B. S., McKinney, D. B., Hulen, J. B., Moore, J. N., and Samberg, S. M., 1978, Geology of Roosevelt Hot Springs KGRA, Beaver County, Utah: University of Utah Research Institute, Earth Science Laboratory 12, 120 p.

Noble, D. C., McKee, E. H., Hedge, C. E., and Blank, H. R., Jr., 1968, Reconnaissance of the Caliente depression, Lincoln County, Nevada [abs]: Geological Society of America Special Paper 115, p. $435-436$.

Noble, D. C., and McKee, E. H., 1972, Description and K-Ar ages of volcanic units of the Caliente volcanic field, Lincoln County, Nevada, and Washington County, Utah: Isochron/West, no. 5, p. 17-24.

Parkinson, Gerald, 1974, Golden pilot plant points way to 500,000-tpy alumina-from-alunite mine and plant in Utah: Engineering and Mining Journal, v. 175, p. 75-78.

Pierce, C. R., 1974, Geology of the southern part of the Little Drum Mountains, Utah: Brigham Young University Geology Studies, v. 21 , pt. 1, p. 109-130.

Ritzma, H. R., 1972, Six Utah "hingeline" wells, in Baer, J. L., and Callaghan, Eugene, eds., Plateau-Basin and Range Transition Zone, Central Utah, 1972: Utah Geological Association Publication 2, p. 75-80.

Rowley, P. D., 1968, Geology of the southern Sevier Plateau, Utah: Unpublished Ph.D. thesis, Austin, University of Texas, $385 \mathrm{p}$. 1975, Geologic map of the Enoch NE quadrangle, Iron County, Utah: U.S. Geological Survey Geologic Quadrangle Map GQ-1301.

1976, Geologic map of the Enoch NW quadrangle, Iron County, Utah: U.S. Geological Survey Geologic Quadrangle Map GQ-1302.

1978, Geologic map of the Thermo 15-minute quadrangle, Beaver and Iron Counties, Utah: U.S. Geological Survey Geologic Quadrangle Map GQ-1493. 
1979, Geologic map of the Marysvale SE quadrangle, Piute County, Utah: U.S. Geological Survey Miscellaneous Field Studies Map MF - 1115.

Rowley, P. D., Anderson, J. J., and Williams, P. L., 1975, A summary of Tertiary volcanic stratigraphy of the southwestern High Plateaus and adjacent Great Basin, Utah: U.S. Geological Survey Bulletin 1405-B, 20 p.

Rowley, P. D., Anderson, J. J., Williams, P. L., and Fleck, R. J., 1978a, Age of structural differentiation between the Colorado Plateaus and Basin and Range provinces in southwestern Utah: Geology, v. 6, p. 51-55.

$1978 \mathrm{~b}$, Age of structural differentiation between the Colorado Plateaus and Basin and Range provinces in southwestern Utah - Reply: Geology, v. 6, p. 572-575.

Rowley, P. D., and Barker, D. S., 1978, Geology of the Iron Springs mining district, Utah, in Shawe, D. R., and Rowley, P. D., eds., International Association on Genesis of Ore Deposits, Guidebook to mineral deposits of southwestern Utah: Utah Geological Association Publication 7, p. 49-58.

Rowley, P. D., Cunningham, C. G., Anderson, J. J., and Steven, T. A., 1979, Geologic map of the Marysvale SW quadrangle, Piute County, Utah: U.S. Geological Survey Miscellaneous Field Studies Map MF-1116. (In press.)

Rowley, P. D., Lipman, P. W., Mehnert, H. H., Lindsey, D. A., and Anderson, J. J., 1978, Blue Ribbon lineament, an east-trending structural zone within the Pioche mineral belt of southwestern Utah and eastern Nevada: U.S. Geological Survey Journal of Research, v. 6, p. 175-192.

Rowley, P. D., and Threet, R. L., 1976, Geologic map of the Enoch quadrangle, Iron County, Utah: U.S. Geological Survey Geologic Quadrangle Map GQ-1296.

Shawe, D. R., Rowley, P. D., Heyl, A. V., and Poole, F. G., 1978, Road $\log$ of field excursion C-2 route, August 21-25, 1978, southwestern Utah, in Shawe, D. R., and Rowley, P. D., eds., International Association on Genesis of Ore Deposits, Guidebook to mineral deposits of southwestern Utah: Utah Geological Association Publication 7, p. 9-34.

Shawe, D. R., and Stewart, J. H., 1976, Ore deposits as related to tectonics and magmatism, Nevada and Utah: Society of Mining Engineers AIME Transactions, v. 260, p. 225-232.

Shuey, R. T., Caskey, C. F., and Best, M. G., 1976, Distribution and paleomagnetism of the Needles Range Formation, Utah and Nevada: American Journal of Science, v. 276, p. 954-968.

Smith, R. B., and Sbar, M. C., 1974, Contemporary tectonics and seismicity of the western United States with emphasis on the Intermountain Seismic belt: Geological Society of America Bulletin, v. 85 , p. $1205-1218$.

Smith, T. L., 1957, Geology of the Antimony Canyon area, Garfield and Piute Counties, Utah: Salt Lake City, University of Utah M.S. thesis, 45 p.

Spieker, E. M., 1946, Late Mesozoic and early Cenozoic history of central Utah: U.S. Geological Survey Professional Paper 205-D, p. $117-161$.

1949, The transition between the Colorado Plateaus and the Great Basin in central Utah: Utah Geological Society Guidebook to the geology of Utah, No. 4, $106 \mathrm{p}$.

Stacey, J. S., Zartman, R. E., and NKomo, I. T., 1968, A lead isotope study of galenas and selected feldspars from mining districts in Utah: Economic Geology, v. 63, p. 796-814.

Stanley, K. O., and Collinson, J. W., 1979, Depositional history of the Paleogene-lower Eocene Flagstaff Limestone and coeval rocks, central Utah: American Association of Petroleum Geologists Bulletin. (In press.)
Steven, T. A., 1978, Geologic map of the Sevier SW quadrangle, west-central Utah: U.S. Geological Survey Miscellaneous Field Studies Map MF-962.

1979a, Geologic map of the Sevier NE quadrangle, westcentral Utah: U.S. Geological Survey Miscellaneous Field Studies Map MF-1108. (In press.)

$1979 \mathrm{~b}$, Geologic map of the Monroe NW quadrangle, westcentral Utah: U.S. Geological Survey Miscellaneous Field Studies Map MF-1107. (In press.)

Steven, T. A., and Cunningham, C. G., 1979a, Clinoptilolite resources in the Tushar Mountains, west-central Utah: U.S. Geological Survey Open-File Report 79-535, 20 p.

$1979 \mathrm{~b}$, Geologic map of the Sevier SE quadrangle, westcentral Utah: U.S. Geological Survey Miscellaneous Field Studies Map MF-1109.

Steven, T. A., Cunningham, C. G., Naeser, C. W., and Mehnert, H. H., 1977, Revised stratigraphy and radiometric ages of volcanic rocks in the Marysvale area, west-central Utah: U.S. Geological Survey Open-File Report 77-569, 45 p.

1979 , Revised stratigraphy and radiometric ages of volcanic rocks in the Marysvale area, west-central Utah: U.S. Geological Survey Bulletin 1469.

Steven, T. A., Cunningham, C. G., and Rowley, P. D., 1978, Geology and mineralization in the Marysvale mining area, west-central Utah, in Shawe, D. R., and Rowley, P. D., eds., International Association on Genesis of Ore Deposits, Guidebook to mineral deposits of southwestern Utah: Utah Geological Association Publication 7, p. 67-70.

Steven, T. A., Rowley, P. D., and Cunningham, C. G., 1978, Geology of the Marysvale volcanic field, west-central Utah, in Geological Society of America, 31st Annual Meeting, Rocky Mountain Section field trip guidebook: Brigham Young University Geology Studies, v. 25, pt. 1, p. 67-70.

Steven, T. A., Rowley, P. D., Hintze, L. F., Best, M. G., Nelson, M. G., and Cunningham, C. G., 1978, Preliminary geologic map of the Richfield $1^{\circ} \times 2^{\circ}$ quadrangle, Utah: U.S. Geological Survey Open-File Report 78-602.

Stewart, J. H., and Carlson, J. E., 1974, Preliminary geologic map of Nevada: U.S. Geological Survey Miscellaneous Field Studies Map MF-609.

Stewart, J. H., Moore, W. J., and Zietz, Isadore, 1977, East-west patterns of Cenozoic igneous rocks, aeromagnetic anomalies, and mineral deposits, Nevada and Utah: Geological Society of America Bulletin, v. 88, p. 67-77.

Stokes, W. L., and Heylmun, E. B., 1963, Tectonic history of southwestern Utah, in Heylmun, E. B., ed., Intermountain Association of Petroleum Geologists Guidebook to the geology of southwestern Utah, Annual Field Conference, 12th: Utah Geological and Mineralogical Survey, p. 19-25.

Stringham, Bronson, 1963, Hydrothermal alteration in the southeast part of the Frisco quadrangle, Beaver County, Utah: Utah Geological and Mineralogical Survey Special Studies, no. 4,21 p.

_ 1964, Alteration area south of the Horn Silver mine, Beaver County, Utah: Utah Geological and Mineralogical Survey Special Studies $9,18 \mathbf{p}$.

Taylor, A. O., and Powers, J. F., 1953, Reconnaissance geologic map of the Wah Wah Range, Beaver County, Utah: U.S. Geological Survey, Open-File Map.

Thomson, K. C., and Perry, L. I., 1975, Reconnaissance study of the Stateline mining district, Iron County, Utah: Utah Geology, v. 1, p. 27-47. 
Threet, R. L., 1963a, Structure of the Colorado Plateau margin near Cedar City, Utah, in Heylmun, E. B., ed., Intermountain Association of Petroleum Geologists Guidebook to the geology of southwestern Utah, Annual Field Conference, 12th: Utah Geological and Mineralogical Survey, p. 104-117.

$1963 \mathrm{~b}$, Geology of the Parowan Gap area, Iron County, Utah, in Heylmun, E. B., ed., Intermountain Association of Petroleum Geologists Guidebook to the geology of southwestern Utah, Annual Field Conference, 12th: Utah Geological and Mineralogical Survey, p. 136-145.

Thurston, W. R., Staatz, M. H., Cox, D. C., and others, 1954, Fluorspar deposits of Utah: U.S. Geological Survey Bulletin 1005, 53 p.

Tobey, E. F., 1976, Geology of the Bull Valley intrusive-extrusive complex and genesis of the associated iron deposits: Eugene, University of Oregon $\mathrm{Ph}$. D. thesis, $244 \mathrm{p}$.

Umshler, D. B., 1975, Source of the Evan's Mound obsidian: Socorro, New Mexico Institute of Mining and Technology M.S. thesis, $32 \mathrm{p}$.

Wells, F. G., 1938, The origin of the iron ore deposits in the Bull Valley and Iron Springs districts, Utah: Economic Geology, v. 33, p. 477-507.
Wender, L. E., and Nash, W. P., 1979, Petrology of Oligocene and early Miocene calc-alkaline volcanism in the Marysvale area, Utah: Geological Society of America Bulletin, pt. II, v. 90, p. 34-476.

Whelan, J. A., 1965, Hydrothermal alteration and mineralization, Staats mine and Blawn Mountain areas, central Wah Wah Range, Beaver County, Utah: Utah Geological and Mineralogical Survey Special Studies 12, 31 p.

Wiley, M. A., 1963, Stratigraphy and structure of the Jackson Mountain- Tobin Wash area, southwest Utah: Austin, University of Texas M.S. thesis, $104 \mathrm{p}$.

Willard, M. E., and Callaghan, Eugene, 1962, Geology of the Marysvale quadrangle, Utah: U.S. Geological Survey Geologic Quadrangle Map GQ-154.

Williams, P. L., 1967, Stratigraphy and petrography of the Quichapa Group, southwestern Utah and southeastern Nevada: Seattle, University of Washington Ph. D. thesis, $139 \mathrm{p}$.

Williams, P. L., and Hackman, R. J., 1971, Geology, structure, and uranium deposits of the Salina quadrangle, Utah: U.S. Geological Survey Miscellaneous Geologic Investigations Map I-591.

Young, R. A., and McKee, E. H., 1978, Early and middle Cenozoic drainage and erosion in west-central Arizona: Geological Society of America Bulletin, v. 89, p. 1745-1750. 